\title{
Can Mesenchymal Stem Cell Transplantation and Fennel Ingestion Alter the Histology of Senile Diabetic Rat Ovary?
}

\author{
Original \\ Article \\ ${ }^{1}$ Hekmat A. Ahmed Sorour, ${ }^{1}$ Fatma S. Abdel Aal, ${ }^{2}$ Hala G. Metwally, \\ ${ }^{1}$ Mona M. Abd-Elgalil \\ ${ }^{1}$ Histology department- Faculty of Medicine for Girls- Al Azhar University. \\ ${ }^{2}$ Clinical Pathology department- Faculty of Medicine - Cairo University.
}

\begin{abstract}
Background: The relation between menopausal status and diabetes mellitus remains controversial. However, clinical trials suggest that menopause would speed the progression to diabetes. Reproductive tract dysfunction is a recognized consequence of diabetes obesity syndrome (DOS). Therefore, a possible association between obesity, diabetes mellitus and abnormalities of female reproductive function may occur. Nowadays traditional medicinal plants and spices are commonly used for their possible effects as hypoglycaemic, antidiabetic and folliculogenic agents instead of using synthetic drugs. Recent studies suggest that bone marrow stem cells (BMSCs) are promising grafts to treat a variety of diseases, including reproductive dysfunction.

Aim of the work: The objective of this study was to evaluate the therapeutic implication of MSCs and fennel ingestion on ovarian diabetically induced senile rats.

Materials \& Methods: 24 senile female albino rats were used in this study. They were divided into 4 equal groups: control group, diabetic group, diabetic/MSCs group and diabetic/ MSCs /fennel oil group. Treatments were continued for 8 weeks, and ovarian samples were collected for histological, immunohistochemical and ultrastructure studies.

Blood glucose levels were estimated and serum hormonal analyses were performed.

Results: Induction of diabetes caused variable sizes of typical ovarian follicular cysts and elevation of blood glucose level. Stem cell transplantation showed some amelioration in the ovarian structure and blood glucose level. Administration of both MSCs and fennel oil had the ability to lower the blood glucose level and restore ovarian structure in diabetic rats.

Conclusion: The use of MSCs in regenerative medicine and tissue engineering makes them a promising therapy to treat diabetes mellitus complications. Fennel essential oil could be given to diabetic patients to ameliorate diabetes in addition to its use as a fertility enhancing agent.
\end{abstract}

Received: 02 October 2018, Accepted: 02 November 2018

Key Words: Diabetes mellitus, fennel essential oil, mesenchymal stem cells, ovary.

Corresponding Author: Mona M. Abd-Elgalil, MD, Histology Department, Faculty of Medicine, Alazhar Universty, Cairo, Egypt, Tel.: +20 1090305671, E-mail: medicalmona2009@yahoo.com

ISSN: 1110-0559, Vol. 42, No. 1

\section{INTRODUCTION}

Diabetes mellitus (DM) is the most common life long complex and multifarious metabolic disorder resulting from absolute or relative deficiency of insulin secretion with abnormally chronic hyperglycaemia associated with disturbance of carbohydrate, fat and protein metabolism ${ }^{[1]}$. As the disease progresses, tissue or vascular damage ensues leading to severe long term diabetic complications ${ }^{[2,3]}$.

Postmenopausal obesity is considered a chronic disease that has severe consequences on physical and psychological health, leading to reduced life expectancy and increased health problems ${ }^{[4,5,6]}$.

Several types of evidence suggest that menopause status may be associated with more rapid progression of glucose intolerance and higher risk for developing type II diabetes $^{[4,7,8]}$
Obesity and lipid overload might be associated with tissue damage and organ dysfunction. Reproductive tract dysfunction is a recognized consequence of diabetes obesity syndrome (DOS). In both humans and experimental animals, utero-ovarian function, and metabolic parameters are altered in response to Type II diabetes. Therefore, a possible association between obesity, diabetes mellitus and abnormalities of female reproductive function in several respects may occur ${ }^{[9,10,11]}$.

Recent studies suggest that bone marrow derived mesenchymal stem cells (BMMSCs) are promising grafts to treat a variety of diseases, including reproductive dysfunction. The main functional characteristics of stem cells are their immuno-modulatory ability, capacity for selfrenewal and differentiation for maintaining the integrity of almost all adult tissues of mesodermal origin. Research 
workers have confidence that stem cells, especially pluripotent cells, hold much potential for medical therapies and medical research ${ }^{[12,13,14]}$.

Traditional medicinal plants and spices are commonly used for their possible effects as hypoglycaemic, antidiabetic and folliculogenic agents instead of using synthetic drugs ${ }^{[15,16,17]}$. Numerous studies have shown that fennel essential oil and its individual constituents exhibit novel pharmacological activities as they are considered to be associated with the prevention of diseases thought to be induced by oxidative stress ${ }^{[18]}$.

The present study aimed to clarify the changes in ovarian cytoarchitectural, immunohistochemical, endocrinal expression and related plasma hormonal levels in diabetically induced senile rats. Moreover, therapeutic implication of mesenchymal stem cells and/or fennel ingestion will also be evaluated.

\section{MATERIALS AND METHODS}

Twenty four senile female albino rats weighing 280330 g. aging 18-20 months were used in the current experiment. Rats were divided equally into 4 groups: each containing 6 rats: GI Control group, that was further subdivided into three subgroups: subgroup Ia: which served as a negative control, subgroup Ib: included rats which received equivalent volume of $0.01 \mathrm{M}$ citrate buffer (solvent of streptozotocin), subgroup Ic: included animals that received equivalent volume of phosphate buffer saline, GII diabetic group: animals received an intraperitoneal (IP) single dose of freshly prepared streptozotocin (STZ) at a dose $60 \mathrm{mg} / \mathrm{kg}$ body weight dissolved in $0.01 \mathrm{M}$ citrate buffer ${ }^{[19]}$, (STZ was purchased from Sigma Company, St.Louis, Mo, USA), GIII diabetic / MSCs group: animals were given STZ and were injected with $1 \mathrm{ml} / \mathrm{kg}$ body weight of cultured and labeled bone MSCs suspension in phosphate buffer saline (PBS) in the tail vein ${ }^{[20]}$, GIV diabetic / MSCs/ fennel oil group: Animals received the same IP single dose of STZ, injected with $1 \mathrm{ml} / \mathrm{kg}$ body weight of cultured, labeled bone MSCs suspension ${ }^{[20]}$ and were daily administered fennel oil by a gastric tube in a dose of $2 \mathrm{ml} / \mathrm{kg}$ body weight ${ }^{[16]}$.

The bone marrow was harvested and isolated by flushing the femurs and tibae of 6 weeks old female albino rats according to the method of ${ }^{[20]}$. The samples were cultured for 3 days and labeling of MSCs was performed. MSCs were suspended in phosphate buffer saline (PBS). Labeled cells were histologically assessed using Prussian blue stain ${ }^{[21]}$. The treatments were started on the $3^{\text {rd }}$ day after STZ injection which was considered the first day of experiment. The treatments were continued for 8 weeks. All the experimental animals were daily fed on a balanced diet till the end of this study. The animals of all groups were weighed individually at the beginning of the experiment and at the end just before collecting samples.

Blood glucose levels were measured on overnight (16 hours) fasted rats on the $3^{\text {rd }}$ day after STZ injection in order to insure diabetes and at the end of the experiment
( 8 weeks). At the end of the experiment rats were lightly anaesthetized with ether and blood samples were collected immediately in sterile tubes from the orbital sinus of each rat using a heparinized capillary tube. The separated serum samples were analyzed for hormonal assay Estradiol (E2), Progesterone and Luteinizing Hormone $(\mathrm{LH})^{[22]}$. The hormonal levels were measured by an automated electrochemiluminescence immunoassay (ECL) technology using Roche cobas e 411 immunoassay analyzer (Manheim, Germany).

Ovarian samples were collected, fixed in $10 \%$ formalin for 2 days $^{[23]}$ and processed to obtain paraffin $4 \mu \mathrm{m}$ thick sections. Sections were stained with haematoxyline \& eosin (H\&E) for routine histological examination, Masson's trichrome stain, for staining the collagen fibers ${ }^{[24]}$ and Perls Prussian blue staining technique, for detection of iron oxide labeled therapeutic stem cells ${ }^{[21]}$.

For electron microscopic preparation, small pieces from each animal were fixed immediately in 5\% glutaraldhyde for $24 \mathrm{~h}$. The specimens were processed and ultrathin sections were prepared ${ }^{[25]}$ and examined using an electron microscope JEOL, TEM 1010 (Tokyo, Japan) in the electron microscopic unit of the Regional Center for Mycology and Biotechnology (RCMB), Al Azhar university.

Immunohistochemical study, the immunohistochemical technique was used in this work to localize the distribution of estrogen receptors alpha $(\mathrm{ER} \alpha)$ in the various ovarian cell types ${ }^{[26]}$.

Paraffin sections are deparaffinized with xylene and rehydrated in graded series of ethanol. The process of antigen retrieval was performed in phosohate buffered saline (PBS) bath. Endogenous peroxidase activity was blocked using hydrogen peroxide for 10-15 minutes at 37 ${ }^{\circ} \mathrm{C}$. Tissue sections were washed gently 3 times with PBS buffer for 2 minutes and then 2 drops $(100 \mu l)$ of primary $\mathrm{Ab}$ mouse monoclonal antibodies were applied to each section to completely cover tissue and incubated at room temperature in moist chamber for 30-60 minutes. Tissue sections were rinsed 3 times with PBS for 2 minutes. 2 drops $(100 \mu \mathrm{l})$ or enough to completely cover tissue, of biotinylated secondary $\mathrm{Ab}$ were added to each section and incubated at room temperature in moist chamber for 10 minutes. Sections were gently washed with buffer and kept in the buffer bath in a humid chamber for 2 minutes. 2 drops $(100 \mu \mathrm{l})$ or a sufficient amount of streptavidin biotin peroxidase was then added to completely cover tissue and incubated for $10 \mathrm{~min}$. at room temperature in moist chamber followed by washing. Peroxidase-compatible chromogen (DAB) mixture was added to the sections and incubated for 5-15 min. followed by washing in distilled water and counterstaining with Meyer's hematoxylin for 1-3 minutes $^{[26]}$. Slides were washed in tap water and finally the sections were rapidly dehydrated with graded series of alcohol, cleared in xylol and mounted with cover slip. positive and negative control slides were also applied. 


\section{Statistical Studies:}

Data of body weight, blood glucose and hormonal levels; Estradiol (E2), Progesterone and Luteinizing Hormone (LH) were computerized and expressed as mean \pm standard deviation "SD" for statistical analysis . Statistical studies were applied using "ANOVA" test. Statistical significance level was defined as $\mathrm{P} \leq 0.05$.

\section{RESULTS}

\section{Histological results}

\section{$H \& E$ stain (Figs.1,2\&3)}

Light microscopic examination of ovarian tissues of the control group (GI) showed the ovarian surface epithelium represented as a single layer of flattened cells with flattened nuclei overlying a thin tunica albuginea layer. Corpora lutea bulged into the ovarian surface giving it a lobulated appearance. The main bulk of corpus luteum was formed of small groups of large granulosa lutein cells with eosinophilic cytoplasm and centrally located vesicular nuclei. The ovarian medulla contained richly vascularized loose connective tissue with many relatively large contorted blood vessels and interstitial glandular cells. No changes had been observed between the different control subgroups.

The ovarian sections of the diabetic group (GII) revealed polycystic ovary ( $\mathrm{PCO}$ ) appearance with the presence of typical follicular cysts of variable size bulging into the ovarian surface giving it a lobulated appearance. Within follicular cysts, oocytes were absent and a decreased thickness of the degenerative membrana granulosa cells was encountered. The follicles were surrounded by hyperplastic thecal cells.

The corpus luteum appeared abnormal with vacuolated granulosa lutein cells. Some cells had large intracytoplasmic vacuoles pushing the nucleus to the periphery of the cell. Other cells had multiple intracytoplasmic vacuoles of different sizes and centrally located deeply stained rounded nuclei. Areas of hemorrhage and interstitial cells that appeared as large closely packed polyhedral cells with vacuolated cytoplasm and deeply stained nuclei appeared within the ovarian medulla.

Diabetic/ MSCs group (GIII) revealed prominent structural improvement when compared to the diabetic only group. Various kinds of growing follicles at different developmental stages, multilaminar primary and secondary follicles appeared bulging into the ovarian surface giving it a lobulated appearance. The main bulk of corpus luteum was apparently normal, formed of small groups of large granulosa lutein cells with rich network of capillaries and theca lutein cells more or less as the control .Closer observation revealed multiple spindle shaped cells inbetween some corpora luteal cells.

Sections of Diabetic/MSCs/fennel group (IV) showed various kinds of growing follicles at different developmental stages, multilaminar primary follicles and Graafian follicles. Multilaminar primary follicle had several layers of granulosa cells surrounded by the theca folliculi. Granulosa lutein cells of corpus luteum were apparently normal and theca lutein cells more or less as the control.There was infiltration with multiple spindle shaped, flat basophilic cells in-between some corpora luteal cells.

\section{Masson's trichrome stain (Fig.4)}

Masson's trichrome stained sections of control group (GI) demonstrated well developed thin layer of tunica albuginea beneath the surface epithelium. Corpora lutea and Corpora albican were observed within the ovarian cortex with delicate collagen fibers in between the cells. Delicate collagen fibers admixed with ground substance with normal density and distribution around many blood vessels were observed within the ovarian medulla. No changes had been observed between the different control subgroups.

Sections of the Diabetic group (II) revealed increase of the density and distribution of the collagenous fibers within the ovarian medulla especially around dilated congested blood vessels. Corpus albicans appeared as a mass of delicate collagenous connective tissue.

Diabetic/ MSCs group (III) sections revealed normal distribution of collagenous fibers beneath surface epithelium. Delicate collagen fibers admixed with ground substance and around blood vessels were observed within the ovarian medulla that appeared more or less similar to the control.

Diabetic/MSCs / fennel group (IV) seactions revealed delicate collagen fibers admixed with ground substance with apparently normal distribution and density of collagen fibers around blood vessels within the ovarian medulla that appeared more or less similar to the control.

\section{Prussian blue stain (Fig.5)}

Prussian blue stained sections of control group (GI) and diabetic group (GII) showed negative staining with Prussian blue and counter staining with neutral red among the surface epithelium, tunica albugenia, ovarian stroma and corpora lutea. No changes had been observed between the different control subgroups.

Sections of Diabetic /MSCs group (GIII) revealed multiple Prussian blue positive ( + ve) cuboidal, polygonal and spindle shaped cells between the ovarian surface epithelium and between granulosa lutein cells of corpus luteum .

Sections of Diabetic/ fennel /MSCs group (IV) revealed multiple Prussian blue positive (+ve) cuboidal and spindle shaped cells between the ovarian surface epithelium and between granulosa lutein cells of corpus luteum.

\section{Immunohistochemical results (Fig.6)}

Examination of the control group (G.I) showed strong brown immunohistochemical reaction of ER $\alpha$ among the surface flattened epithelium and granulosa lutein cells of corpus luteum. 
Diabetic group (G.II): showed weak cytoplasmic expression of ER $\alpha$ among the remaining membrana granulosa cells of follicular cyst.

Diabetic /MSCs group (G.III): showed strong cytoplasmic expression of ER $\alpha$ was clearly observed among the ovarian surface epithelium and membrana granulosa cells of Graafian follicle.

Diabetic /MSCs/fennel group (G.IV): showed high level of cytoplasmic expression of ER $\alpha$ among ovarian surface epithelium and membrana granulosa cells of secondary follicle.

\section{Electron microscopic examination}

Examination of control group (GI) demonstrated single layer of flattened ovarian surface epithelial cells with flattened relatively euochromatic nuclei. Few microvilli projected from the apical surface. The basal lamina separated the surface epithelium from the underlying tunica albuginea which contained cross and longitudinal sections of collagen fibers (Fig.7). Corpora lutea with large polyhedral granulosa lutein cells had euchromatic nuclei with irregular contour.Collagen fibers in different directions separating the granulosa cells from each other . Cytoplasm of the granulosa lutein cells contained mitochondria with tubular cristae and flattened cisternae of rough endoplasmic reticulum. Cross and longitudinal sections of collagen fibers cut in different directions with a characteristic regular periodicity separating the granulosa cells from each other (Fig.8)

Sections of diabetic group (GII) showed degenerated corpora lutea consisted of granulosa lutein cells. The granulosa lutein cells appeared as large polyhedral cells with heterochromatic nuclei with dense chromatin clumps. Obvious changes in granulosa lutein cells revealed accumulation of numerous variable sized electron lucent and electron dense lipid droplets which almost filled the whole cytoplasm (Fig.9) Dilated cisternae of rough endoplasmic reticulum and multiple apparently abnormal degenerated oval to rounded mitochondria, with disrupted cristae and loss of internal organization were scattered within the cytoplasm (Fig.10) . Multivesicular bodies and closely packed vesicles were apparently increased within the luteal cell cytoplasm. Such vesicles were smooth membrane bounded, varied greatly in size and appeared enclosing electron opaque material (Fig.11).

Sections of Diabetic/ MSCs group (GIII) revealed, multilaminar primary follicle presented many layers of granulosa cells surrounded by many layers of theca folliculi that differentiated into polygonal theca interna cells with blood capillaries in-between that contained red blood corpuscles. The granulosa cells had euchromatic nuclei with dense chromatin clumps and shallow indentations (Fig12).Cytoplasm was occupied by apparently normal mitochondria with tubular cristae and parallel stacks of flattened cisternae of rough endoplasmic reticulum with lumina of relatively uniform size (Fig.13). The oocyte multilaminar primary follicle was a large rounded cell, had large spherical and euochromatic nucleus surrounded by a nuclear envelope. Thick layer of well-developed electron semitranlucent zona pellucida separated the oocyte from the surrounding granulosa cells (Fig.14).

Sections of Diabetic/ MSCs/ fennel group (GIV) revealed mature Grafian follicle presented large polyhedral granulosa cells with euochromatic nuclei. These cells were separated by spaces full of liquor folliculi and surrounded by a basement membrane and is separated from the surrounding relatively flattened theca interna cells by a thin layer of collagen fibers cut in different directions (Fig.15). The granulosa cells cytoplasm had plenty of apparently normal mitochondria with tubular cristae and parallel stacks of flattened cisternae of rough endoplasmic reticulum (Fig.16). The oocyte appeared surrounded by a thick layer of well-developed electron semitranlucent zona pellucida separated it from the surrounding granulosa cells. Both oolema and plasma membrane of the granulosa cells were thrown into membranous finger-like processes, microvilli which projected into the wide semitranlucent zona pellucid (Fig.17). Widely dispersed long thin fibroblastlike stem cells having long and thin cell processes. They contained large irregularly shaped euchromatic nuclei with indentations. Heterochromatin around the nuclear margin is distinctly very pronounced. Several mitochondria and rough endoplasmic reticulum were present in the thick zone of cytoplasm, while a relatively thin peripheral rim of cytoplasm is poor in organelles (Fig.18).

\section{Statistical results:}

At the beginning of the experiment the mean values of initial body weight of all studied groups were nearly similar with no statistically significant difference. They ranged from $289+11$ to $293+20$.

At the end of the experiment, diabetic group (II) showed the least recorded mean of final body weight when compared to the other experimental groups, followed by diabetic / MSCs group (III) and the diabetic / MSCs /fennel group (IV) respectively. All these data were presented in (Table 1) and (Histogram 1).

On the 3rd day following STZ injection, the fasting blood glucose levels were within normal in group (I) $(89+10)$. However, the highest mean of blood glucose was recorded in groups (IV).

At the end of the experiment, diabetic group (II) showed the highest level of blood glucose if compared to the other experimental groups. The blood glucose level was within normal in diabetic / MSCs /fennel group (IV) and diabetic / MSCs group (III) respectively. All these data were presented in (Table 2) and (Histogram 2).

As regards the statistical study concerning serum hormone levels among rats of all groups. there was a statistically significant increase in the mean values of serum Estradiol and Progesterone levels, with the highest mean values recorded among group (IV). While, the least 
means values were recorded among diabetic group (II) that showed at the same time the highest mean value of serum LH level . All these data were represented in table (3) and histogram $(3 \& 4)$.

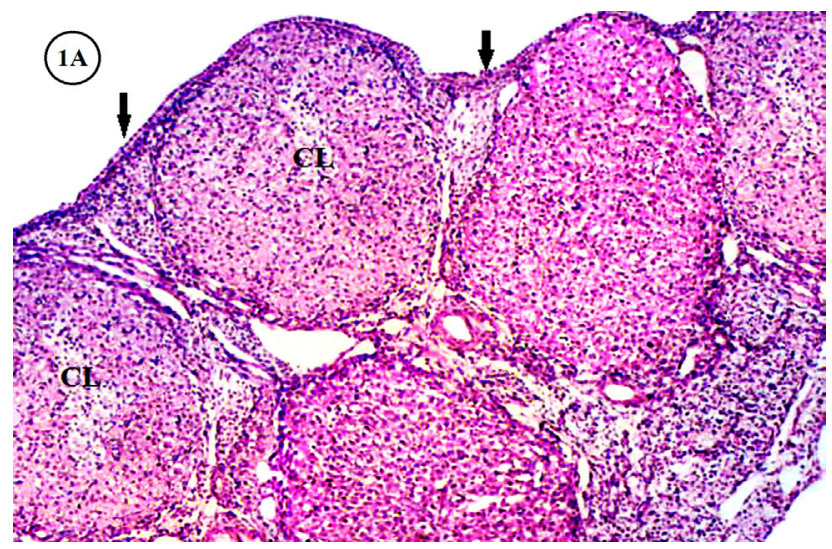

Fig. 1A: A photomicrograph showing: surface epithelium overlying a thin layer of tunica albugenia ( ) Notice, the presence of multiple corpora lutea (CL) obscuring the ovarian corticomedullary junction and bulging into the ovarian surface giving it a lobulated appearance. Richly vascularized loose connective tissue and interstitial cells within the ovarian medulla are seen.

Control-H\&E x100

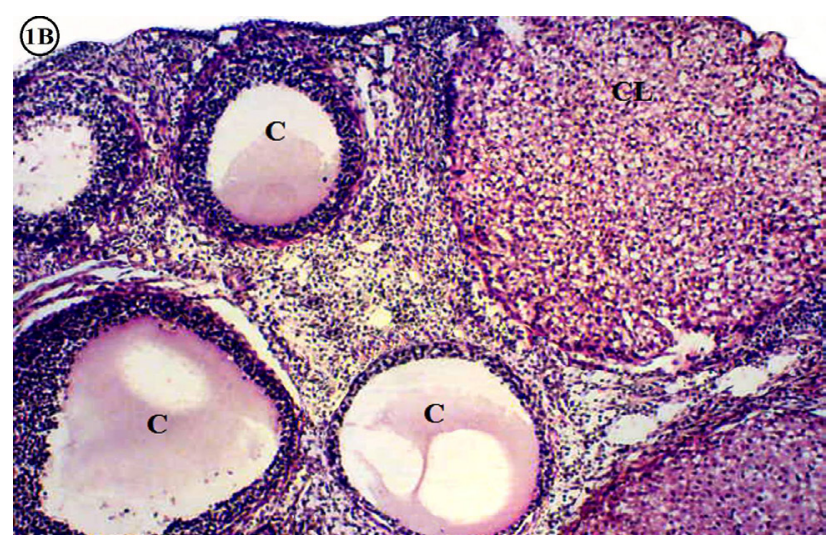

Fig. 1B: A photomicrograph showing: typical follicular cysts (C) of variable sizes . Notice, abnormal corpus luteum (CL) with vaculated granulosa lutein cells.

Diabetic-H\&E x100

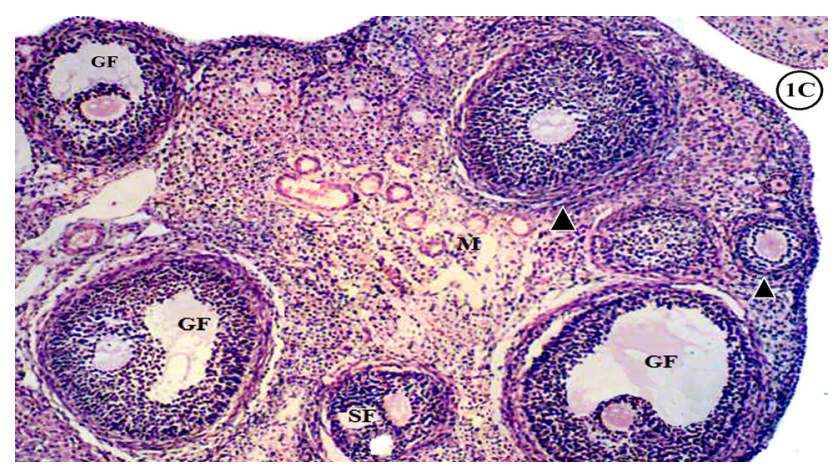

Fig. 1C: A photomicrograph showing: multilaminar primary follicles ( $\mathbf{A}$ ), secondary follicle (SF) and Graafian follicles (GF) within the ovarian cortex. Richly vascularized loose connective tissue and interstitial cells are seen within the ovarian medulla (M). Diabetic / MSC - H\&E $\mathrm{x} 100$

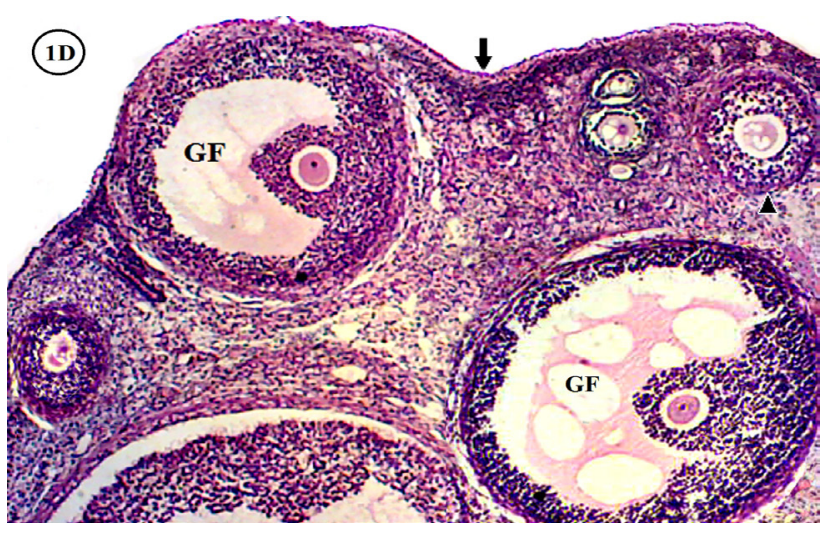

Fig. 1D: A photomicrograph showing: surface epithelium overlying a thin layer of tunica albugenia $(\mathbf{t})$. Notice, The presence of multilaminar primary follicles $(\boldsymbol{\Delta})$ and Graafian follicles (GF) within the ovarian cortex. Diabetic / MSC/fennel - H\&E x100

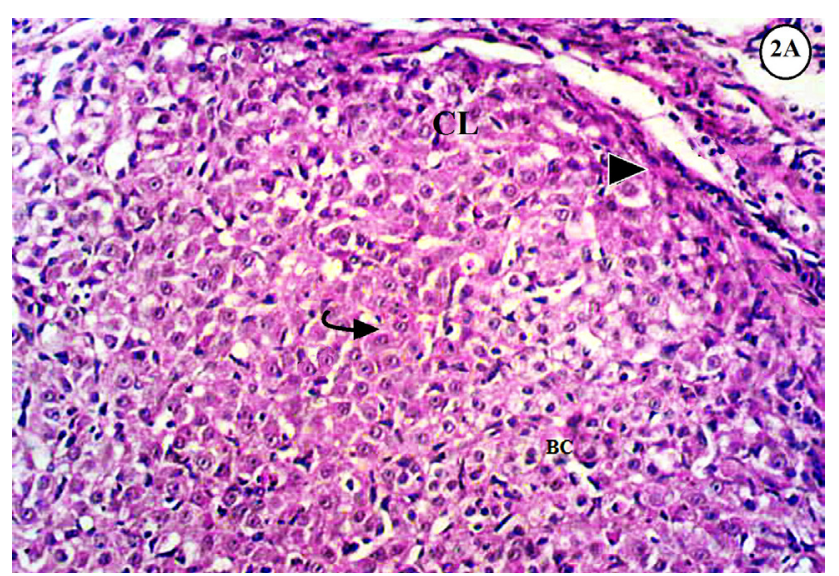

Fig. 2A: A photomicrograph showing: part of corpus lutem (CL) in which the granulosa lutein cells $(\longleftrightarrow$ ) appear as large polygonal cells with eosinophilic cytoplasm and centrally located large round vesicular nuclei. Notice, network of blood capillaries (BC) inbetween the granulosa lutein cells and the surrounding theca lutein cells (

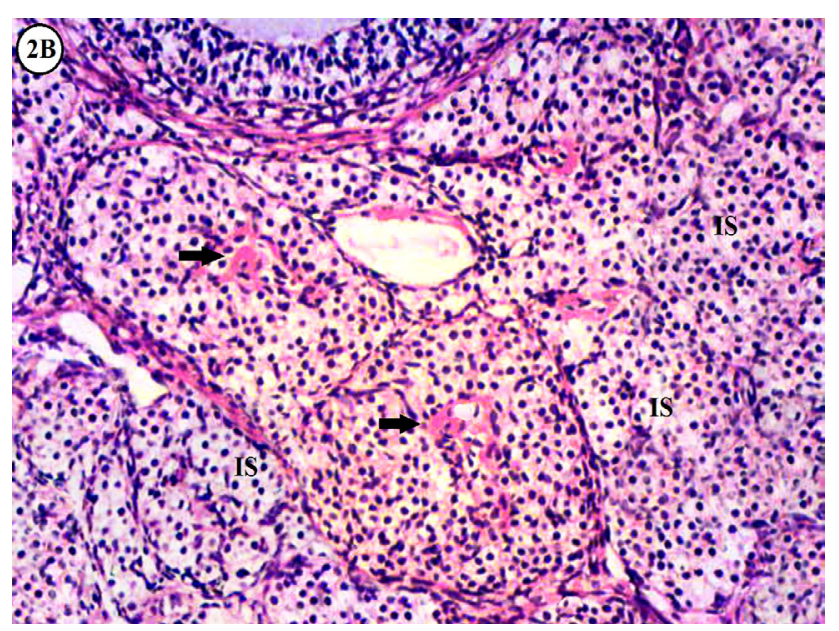

Fig. 2B: A photomicrograph showing: areas of hemorrhage (- ) and interstitial cells (IS) that appear as large closely packed polyhedral cells with vaculated cytoplasm and deeply stained nuclei within the ovarian medulla. 


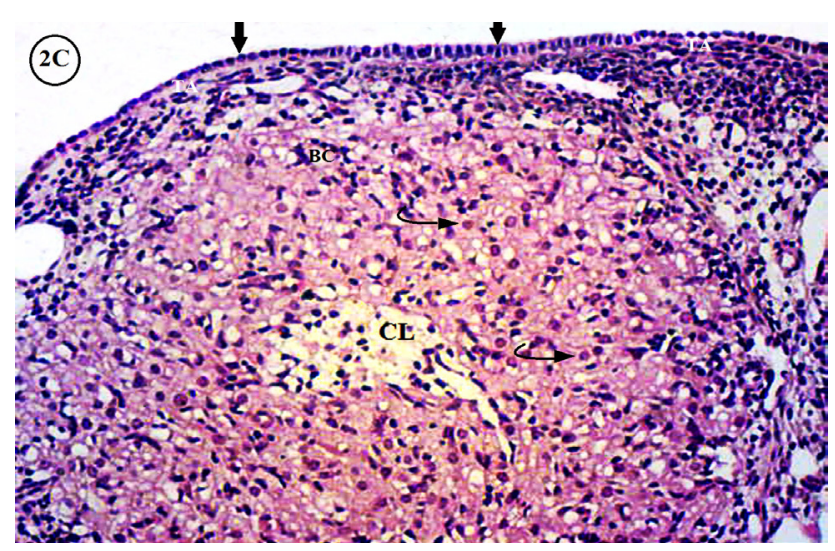

Fig. 2C: A photomicrograph showing: part of corpus luteum (CL) with granulosa lutein cells $(\hookrightarrow)$ and rich network of blood capillaries (BC). Notice, surface epithelium $(\downarrow)$ increase in height from cubical up to columnar cells overlying a thin layer of tunica albugenia (TA)

Diabetic/ MSC - H\&E x200

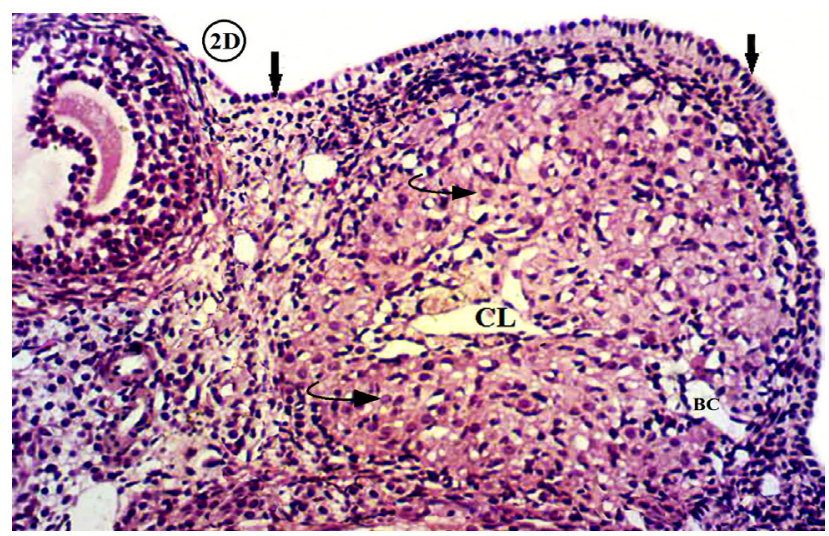

Fig. 2D : A photomicrograph showing: corpus luteum (CL) in which granulosa lutein cells appear as polygonal cells with eosinophilic cytoplasm and centrally located round nuclei $(\hookrightarrow)$ with rich network of blood capillaries (BC). Surface epithelium $(\mathbf{)}$ increase in height from cubical up to columnar cells It overlies a thin layer of tunica albugenia.

Diabetic/MSC/ fennel - H\&E x200

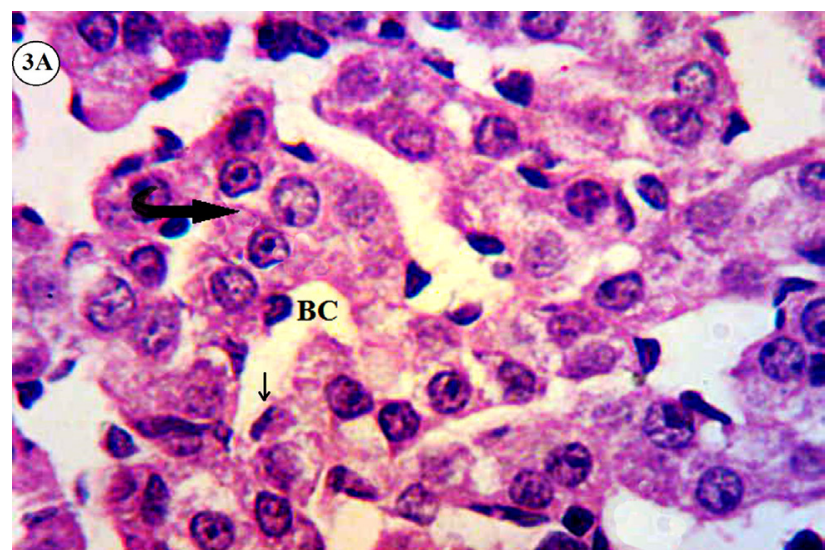

Fig. 3A: A photomicrograph showing: large polygonal granulosa lutein cells with eosinophilic cytoplasm and large round vesicular nuclei $(\longrightarrow)$. Fattened endothelial cells $(\downarrow)$ lining blood capillaries (BC) inbetween the granulosa lutein cells are noticed. Control - H\&E x400

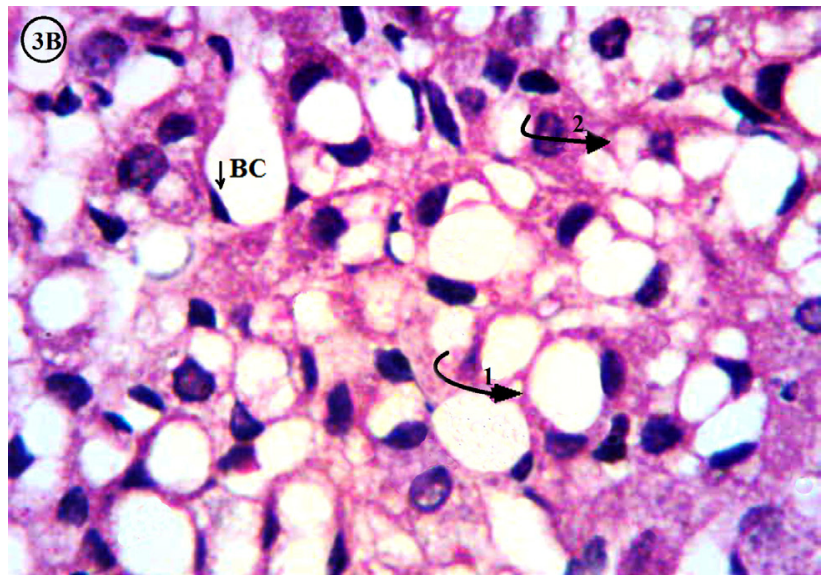

Fig. 3B: A photomicrograph showing: some enlarged granulosa lutein cells occupied by large cytoplasmic vacuoles with peripheral displacement of the nucleus ( 1 ), other cells have multiple intracytoplasmic vacuoles with centrally located nuclei $(\underset{\mathbf{W}}{\mathbf{2}}$ ).Notice, flattened endothelial cells $(\downarrow)$ lining blood capillaries ( BC) inbetween the granulosa lutein cell

Diabetic - H\&E x400

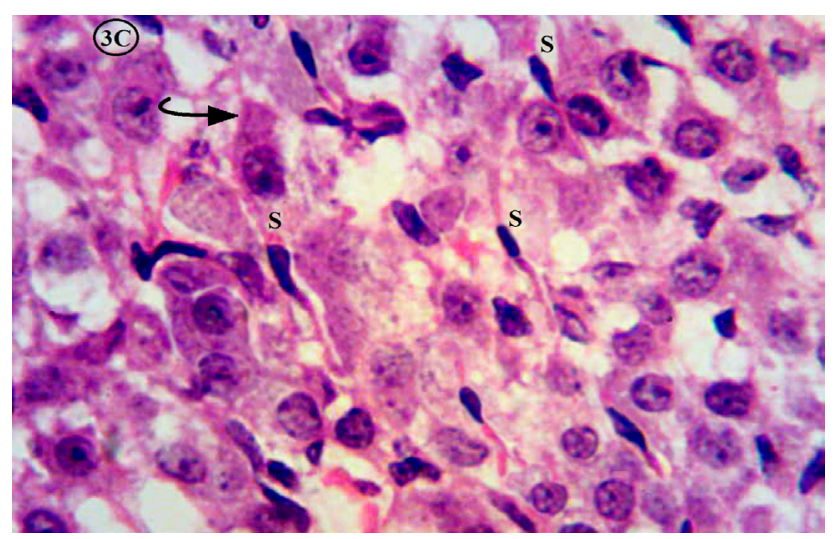

Fig. 3C: A photomicrograph showing: large polygonal granulosa lutein cells with eosinophilic cytoplasm and large round vesicular nuclei $(\longrightarrow$ ). Notice, multiple spindle shaped cells (S) inbetween some granulosa lutein cells.

Diabetic/MSC- H\&E x400

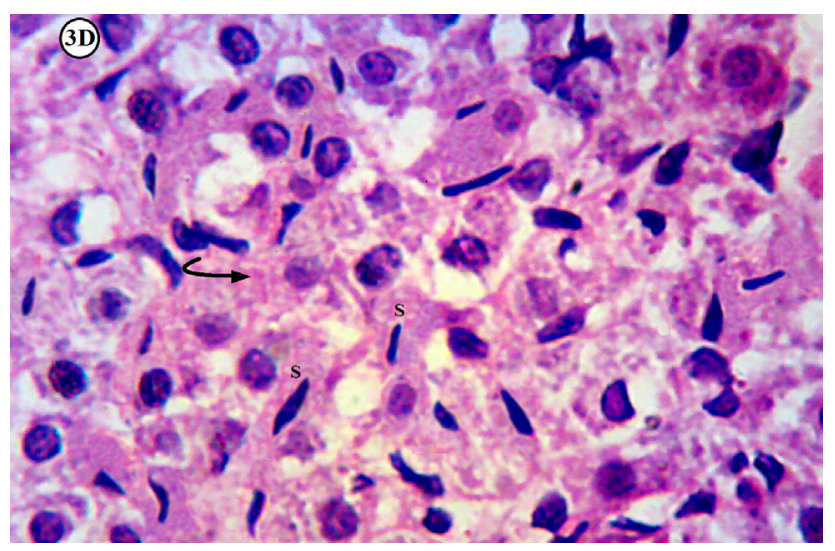

Fig. 3D: A photomicrograph showing: large polygonal granulosa lutein cells with eosinophilic cytoplasm and large round vesicular nuclei ( ). Notice, multiple spindle shaped cells (S) between some granulosa lutein cells. 


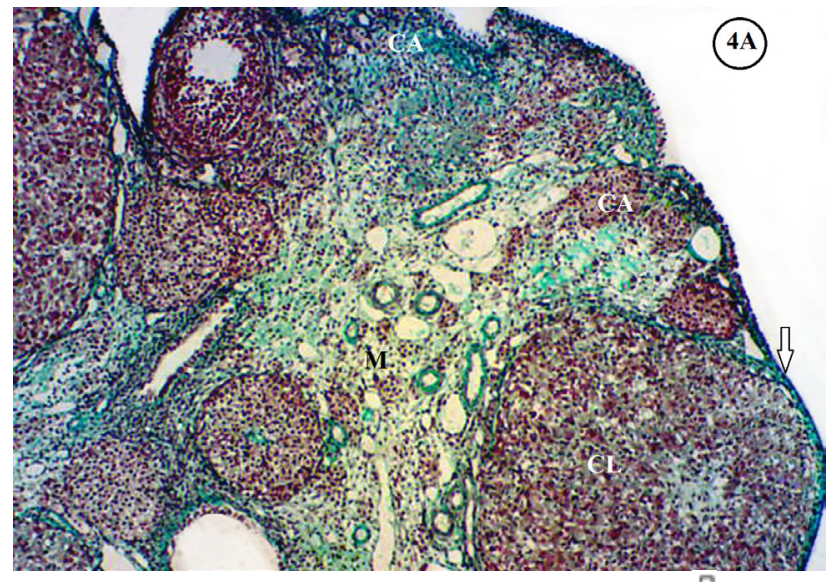

Fig. 4A: A photomicrograph showing: tunica albuginea $(\hat{\gamma})$ beneath the surface epithelium . Corpus lutem (CL) and corpus albican (CA) are observed within the ovarian cortex . Notice.delicate collagen fibres admixed with ground substance within ovarian medulla (M) with normal density and distribution of collagen fibers around medullary blood vessels

Control-Masson's trichrome x100

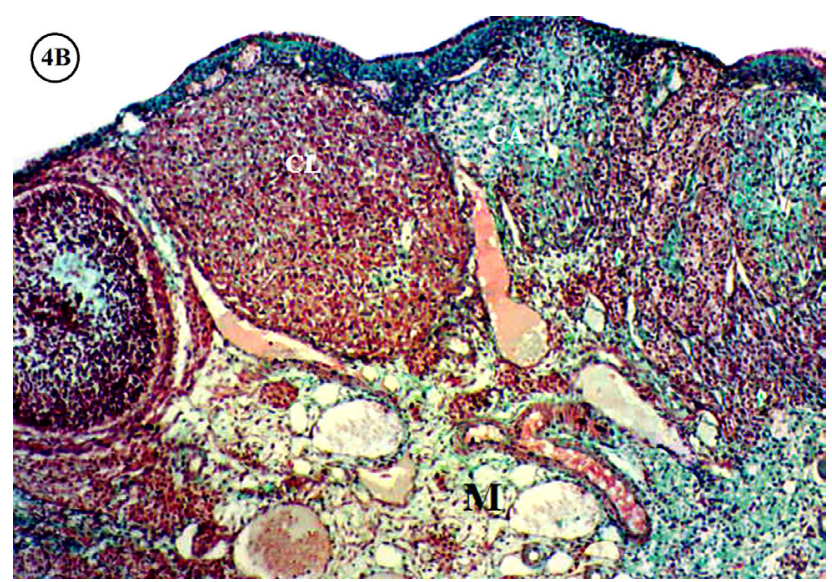

Fig. 4B: A photomicrograph showing: increase in the density and distribution of the collagenous fibers within ovarian medulla (M) especially around dilated congested blood vessels.

Diabetic-Masson's trichrome x 100

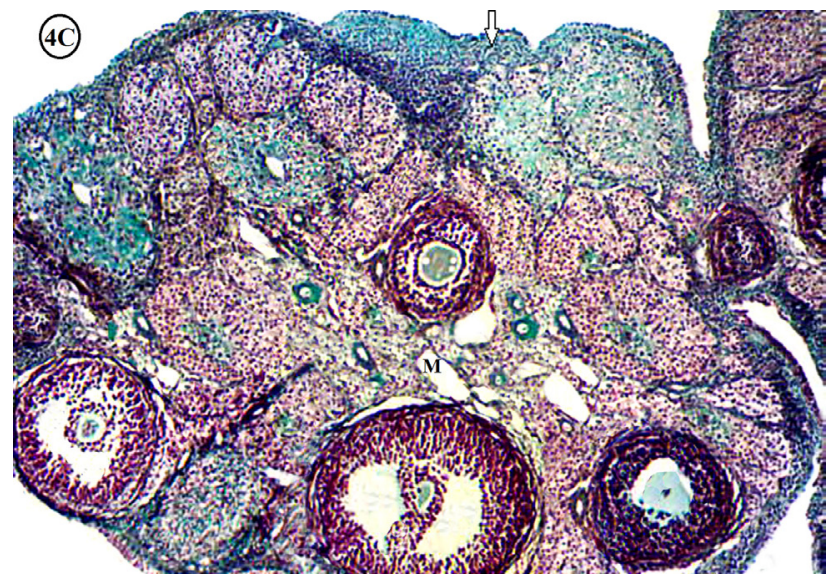

Fig. 4C: A photomicrograph showing: well developed layer of collagenous fibers in tunica albuginea $(\{)$ beneath the surface epithelium. Delicate collagen fibres admixed with ground substance are observed within ovarian medulla (M). Diabetic/ MSC-Masson's trichrome x100

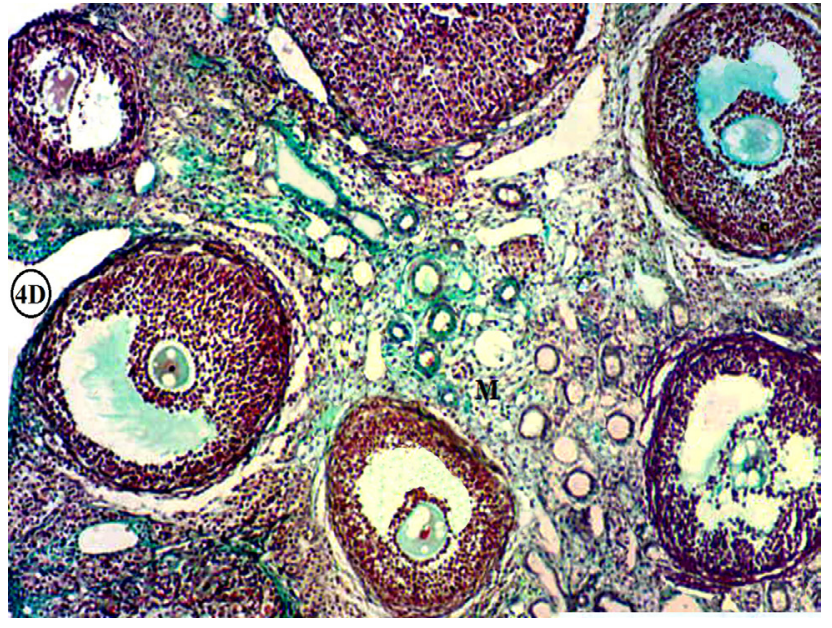

Fig. 4D: A photomicrograph showing: delicate collagen fibres admixed with ground substance within ovarian medulla $(\mathrm{M})$ more or less similar to the control. Diabetic/ MSC/fennel-Masson's trichrome x100

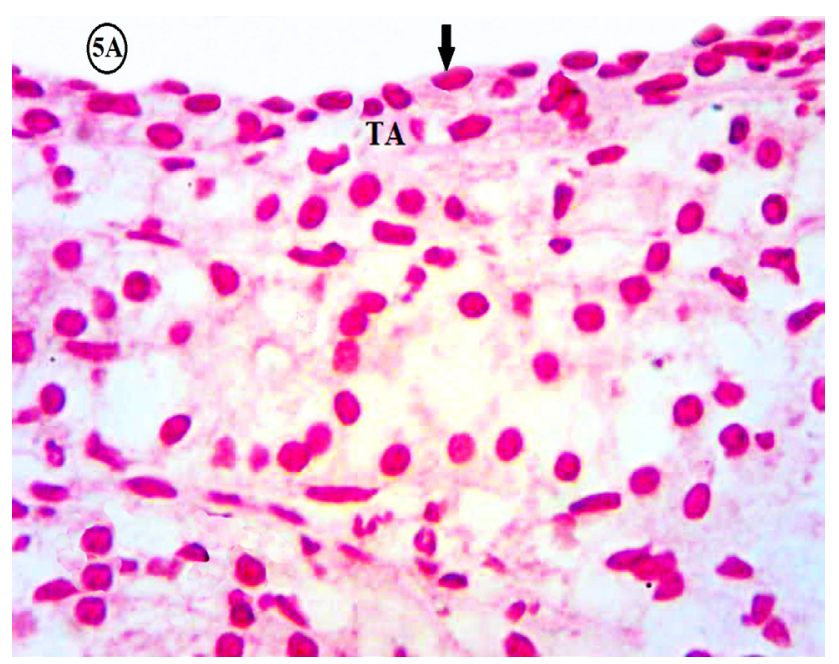

Fig. 5A: A photomicrograph showing: negative staining with Prussian blue and Neutral red in the tunica albuginea (TA) and the surface epithelium ( $)$.

Control-Prussian blue $\mathrm{x} 400$

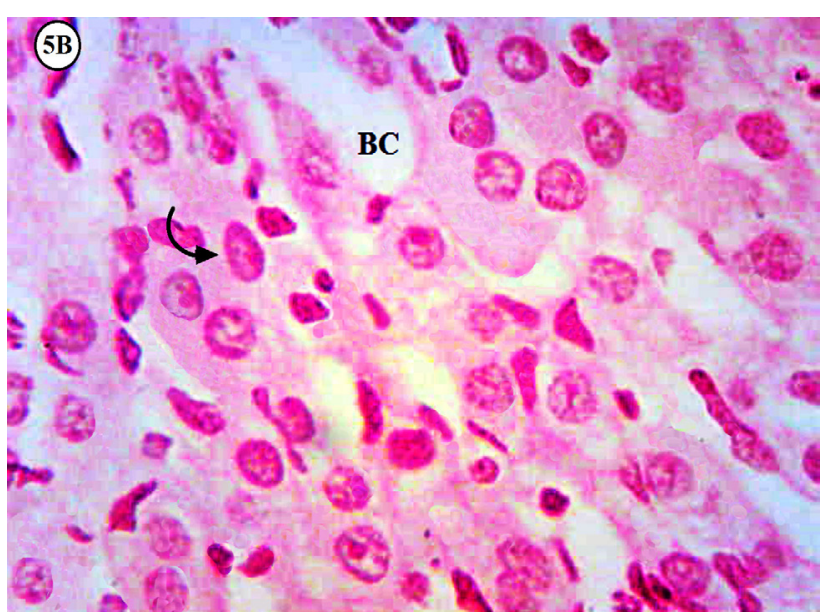

Fig. 5B: A photomicrograph showing: negative reaction with Prussian blue and Neutral red in the granulosa lutein cells of the corpus lutem $(\longleftrightarrow)$ and blood capillaries (BC) in between them. Diabetic - Prussian blue $\mathrm{x} 400$ 


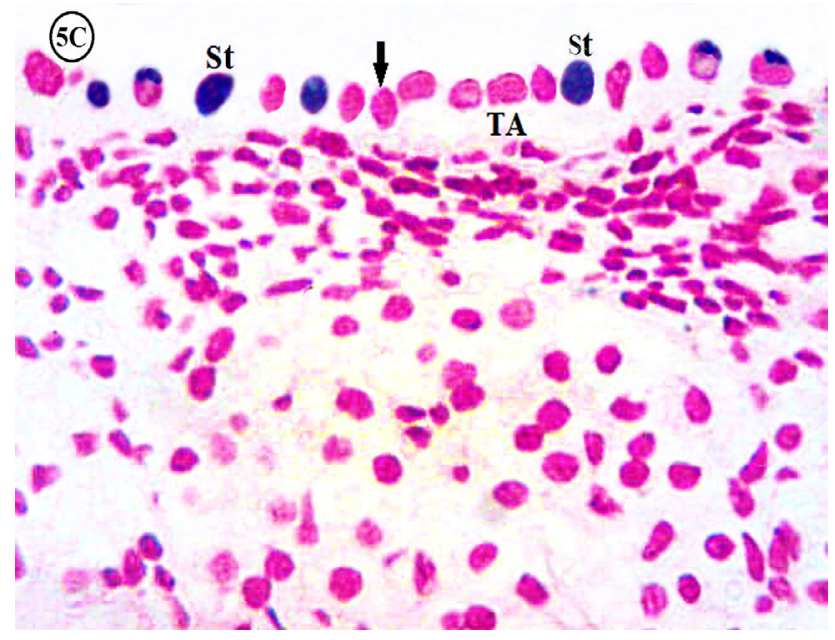

Fig. 5C: A photomicrograph showing: Prussian blue tve cubical stem cells (St) between the cuboidal surface epithelium (that overlies tunica albuginea (TA).

Diabetic/MSC -Prussian blue $\mathrm{x} 400$

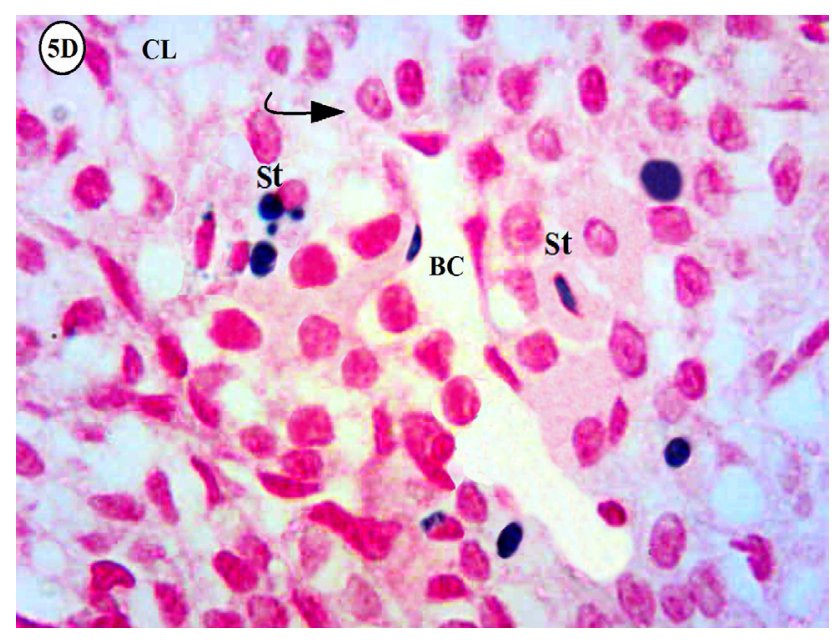

Fig. 5D: A photomicrograph showing: some Prussian blue +ve polygonal and spindle shaped stem cells $(\mathrm{St})$ between granulosa lutein cells $(\longrightarrow)$ of corpus luteum .

Diabetic/ MSCs/ Fennel-Prussian blue x400

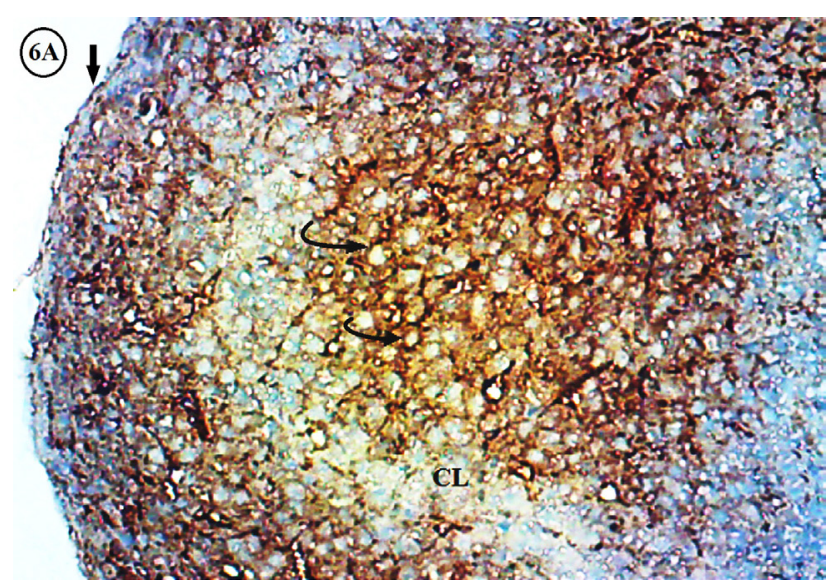

Fig. 6A: A photomicrograph showing: rutoplasmic expression of ERo amnno the ovarian surface epithelium () and granulosa lutein cells

$(\longrightarrow$ ) of corpus luteum (CL). Control ER $\alpha$ immunohistochemical staining x200

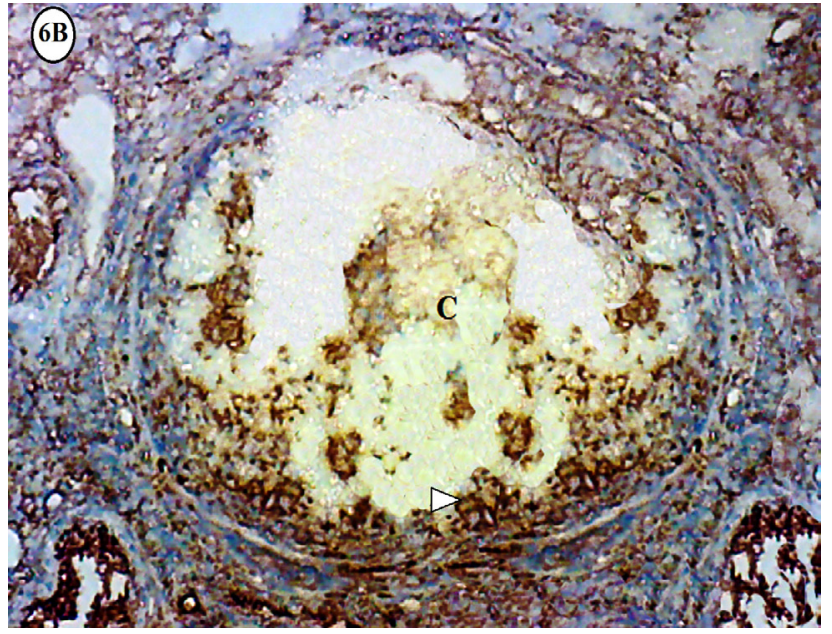

Fig. 6B: A photomicrograph showing: cytoplasmic expression of ER $\alpha$ among few membrana granulosa cells $(\Delta)$ remaining within the follicular cyst (C). Diabetic ER $\alpha$ immunohistochemical staining x200

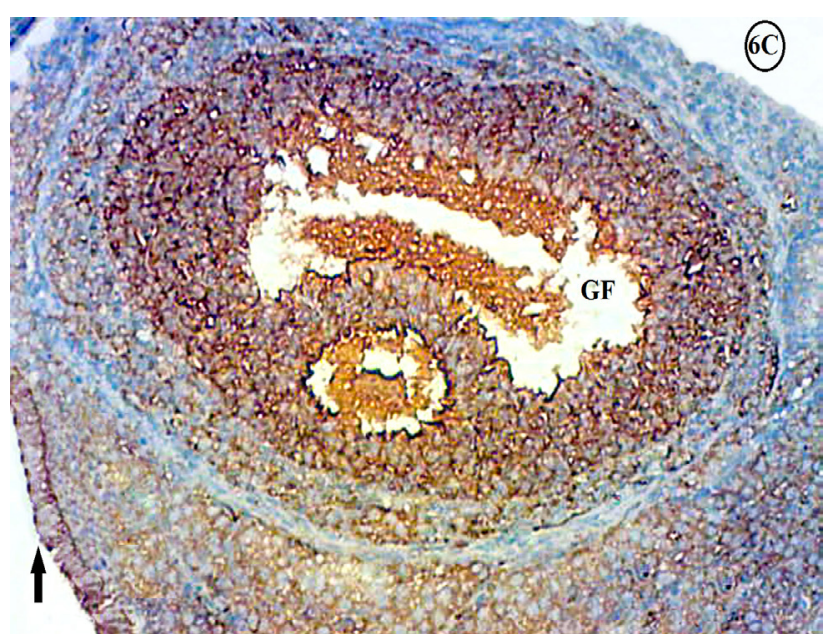

Fig. 6C: A photomicrograph showing: cvtoplasmic expression of ER $\alpha$ among the ovarian surface epithelium ( $)$ and the membrana granulosa cells of Grafian follicle(GF) Diabetic/MSC ER $\alpha$ immunohistochemical staining $\times 200$

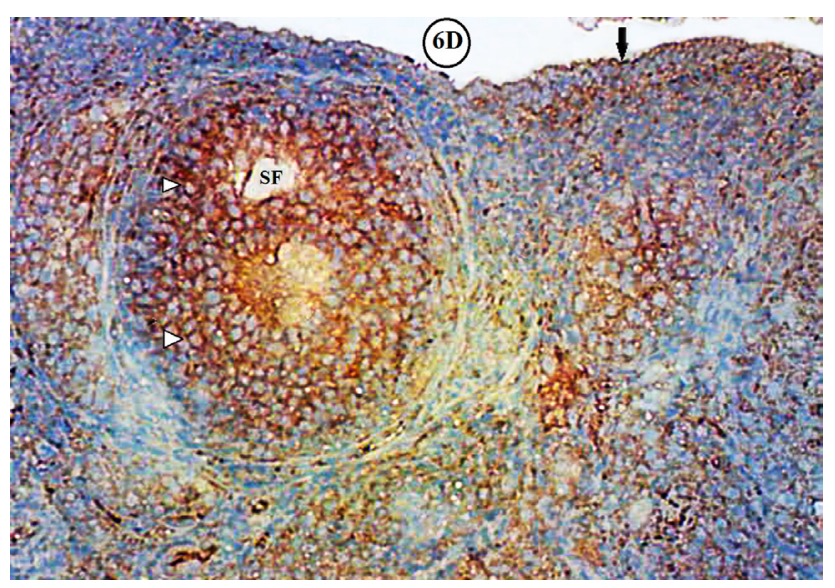

Fig. 6D: A photomicrograph showing: cytoplasmic expression of ERo among the ovarian surface epithelium ( $)$ and granulosa cells $(\longrightarrow)$ of secondary follicle (SF). Diabetic/MSC/fennel ER $\alpha$ immunohistochemical staining x200 


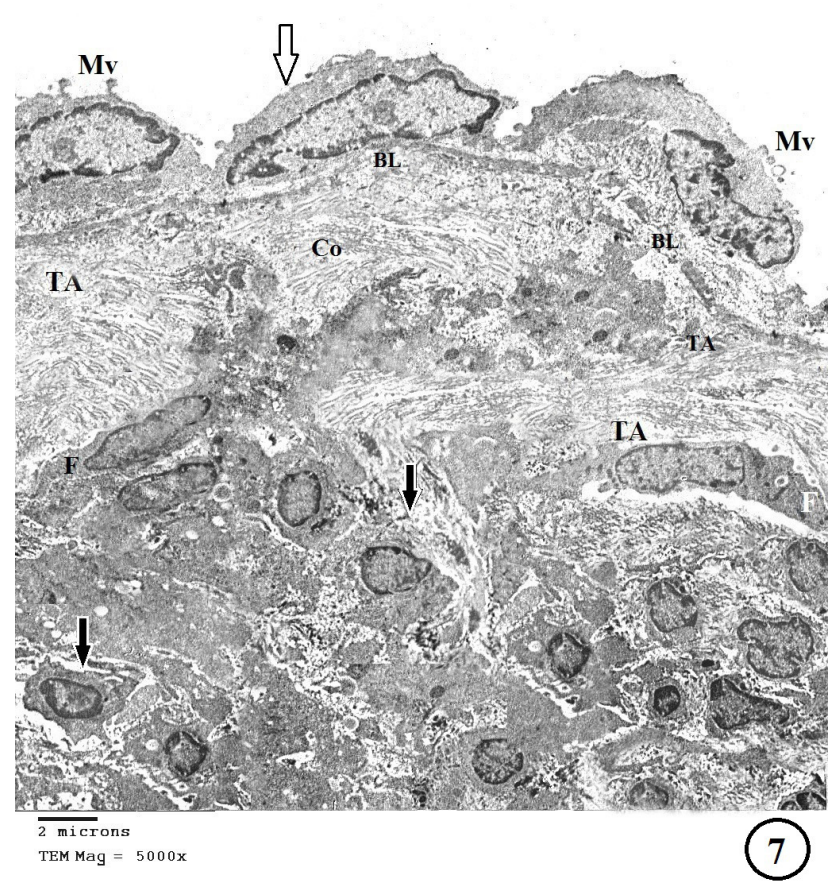

Fig. (7): An electron micrograph showing: flattened surface epithelium with irregular flattened contour euochromatic nuclei and small prominent nucleoli $(\mathfrak{b})$. Few microvilli (Mv) project from the apical surface. Basal lamina (BL) separates surface epithelium from the underlying tunica albugenia (TA) which shows cross and longitudinal sections of collagen fibers (Co). Notice, flattened fibrocytes (F) have elongated flattened nuclei subjacent to the tunica albuginea. Polyhedral stromal cells with relatively heterochromatic oval nuclei $(\downarrow$ ) are embedd in electron dese amorphous material within the ovarian cortex. Control- x 5000

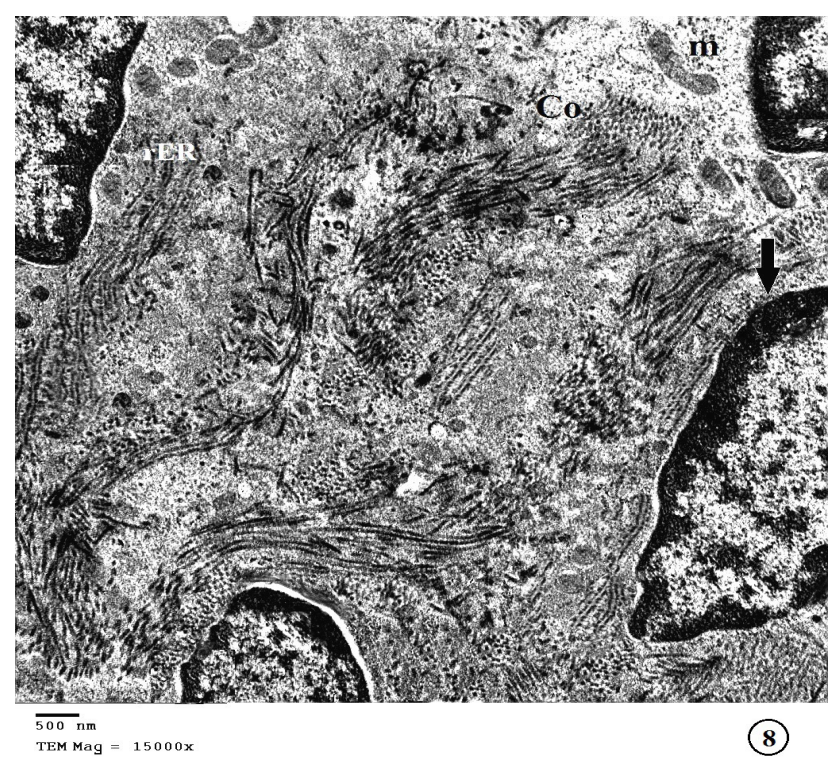

Fig. (8): An electron micrograph of part of degenerated corpus luteum from a control rat (GI), showing: granulosa lutein cells having euchromatic nuclei ( ) containing mitochondria (m) with tubular cristae , parallel stacks of flattened cisternae of rough endoplasmic reticulum (rER) with lumina of relatively uniform size. Notice, cross and longitudinal sections of collagen fibers $(\mathrm{Co})$.

Control- x15000

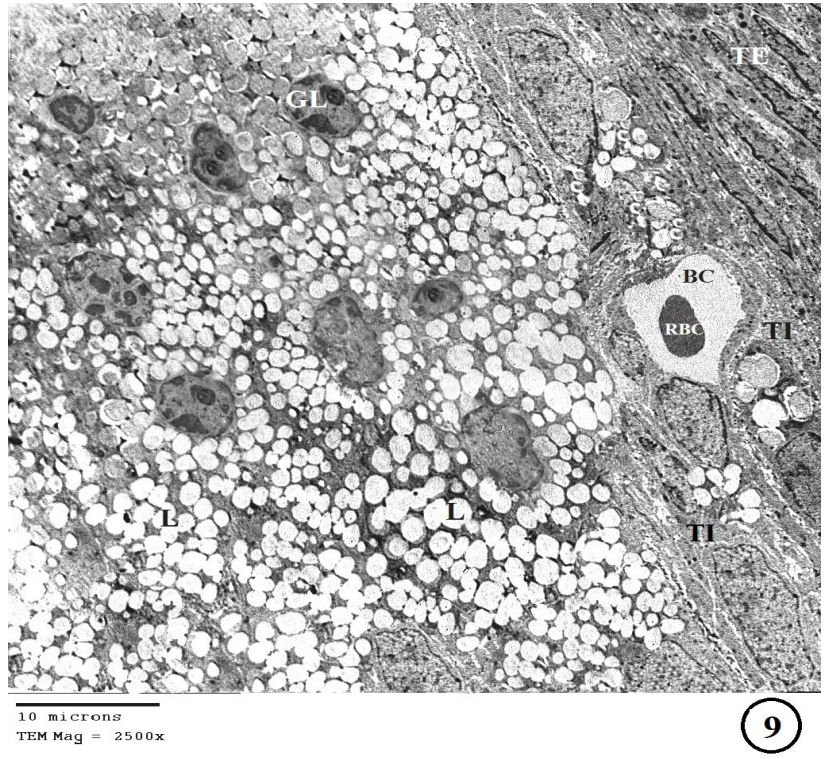

Fig. (9): An electron micrograph of part of degenerated corpus luteum from a diabetic rat (GII), showing: high accumulation of numerous electron lucent lipid droplets (L) of variable sizes filling most of the granulosa lutein cells' cytoplasm (GL). Nuclei are heterochromatic exhibiting differences in size and shape with condensed chromatin clumps. Notice, polyhedral theca lutein interna cells (TI) contain variable sized electron lucent lipid droplets with relatively euchromatic oval nuclei. A blood capillary (BC) contains red blood corpuscle (RBC) is seen. Also flattened theca lutein externa (TE) are observed at the right upper corner.

Diabetic -x 2500

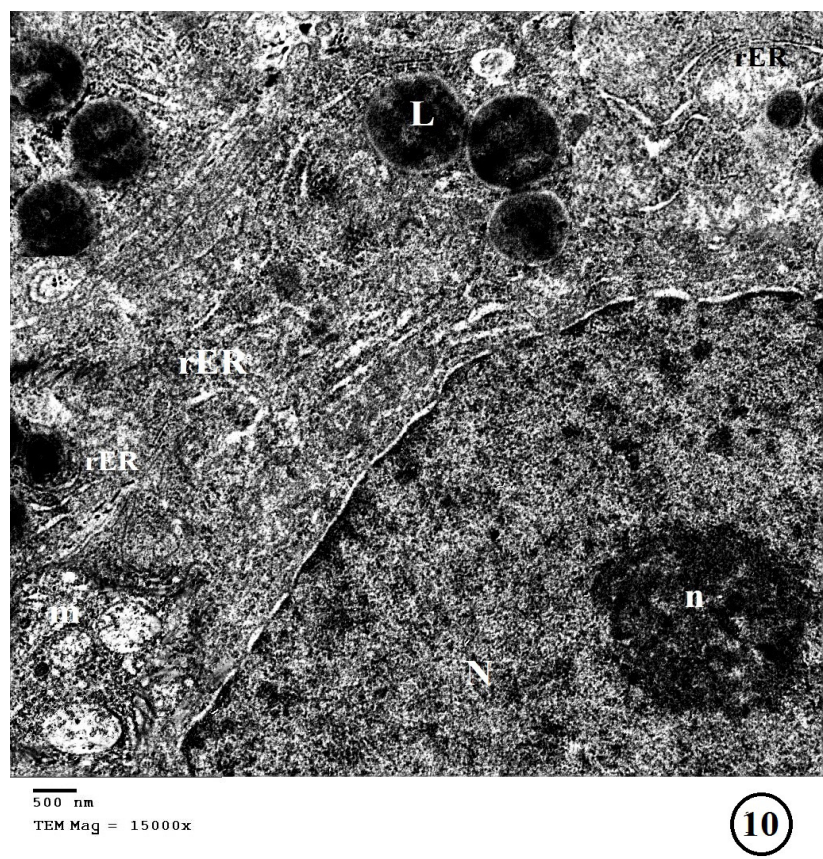

Fig. (10): An electron micrograph of part of corpus luteum showing: nucleus (N) with prominent nucleolus (n) in the nucleoplasm, dilated cisternae of rough endoplasmic reticulum (rER), apparently abnormal degenerated mitochondria $(\mathrm{m})$ : irregular forms, swollen expanded with disrupted cristae and loss of their internal organization. Notice, electron dense lipid droplets (L) of variable sizes within the granulosa lutein cells' cytoplasm. 


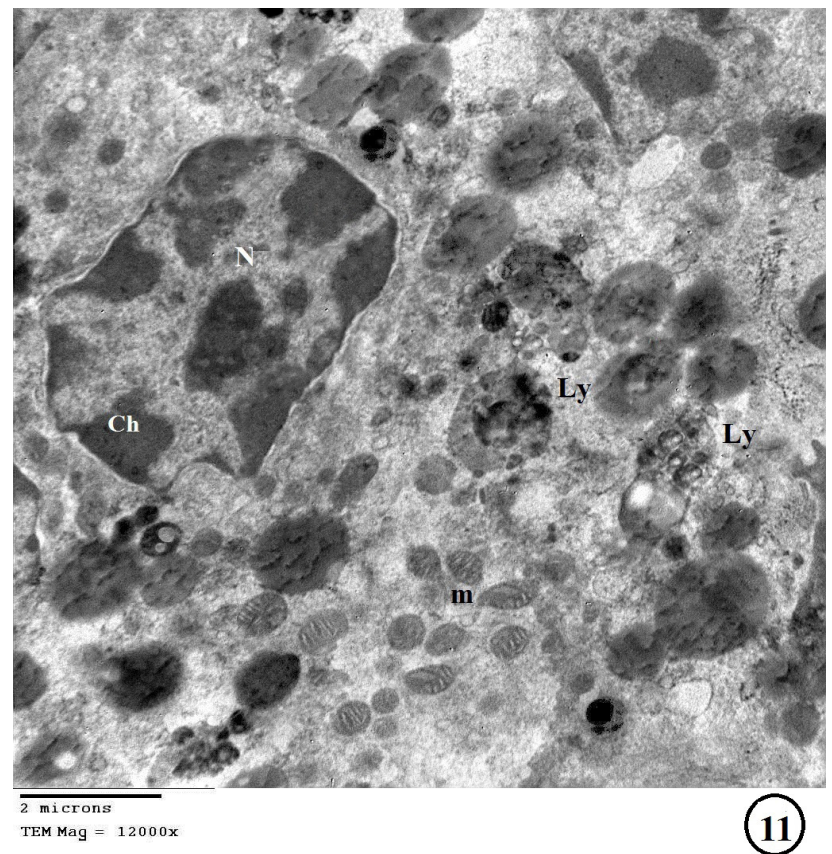

Fig. (11): An electron micrograph of part of degenerative corpus luteum showing: irregular shaped nucleus $(\mathrm{N})$ with condensed chromatin clumps, distributed in the nucleoplasm, large chromatin patches $(\mathrm{Ch})$ attached to the nuclear envelope of degenerated granulosa lutein cell. Multivesicular bodies (secondary lysosomes) (Ly) scattered throughout the cytoplasm. Notice, multiple rounded to oval mitochondria (m) with tubular cristae.

Diabetic-x 12000

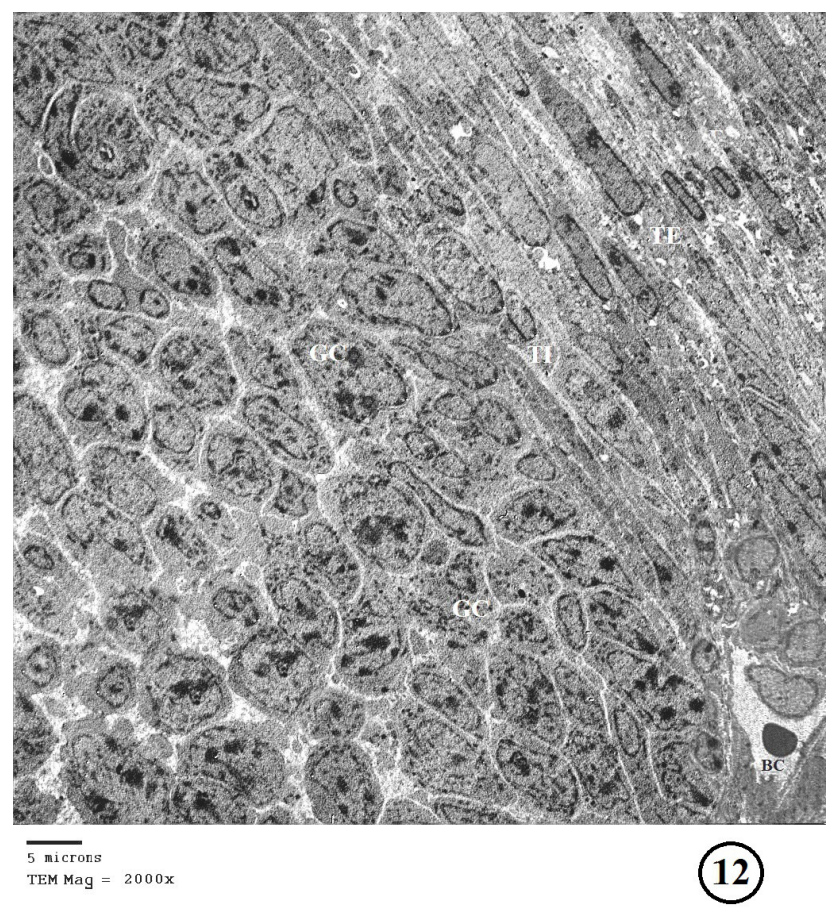

Fig. (12): An electron micrograph of part of multilaminar primary ovarian follicle, showing: many layers of polyhedral granulosa cells (GC) have euchromatic nuclei exhibiting differences in size and shape .They are surrounded by polyhedral theca interna cells (TI), that enclose blood capillary inbetween (BC) which contained red blood corpuscle. Notice, many layers of fibroblast-like flattened theca lutein externa cells (TE) with elongated nuclei.

Diabetic / MSC- x2000

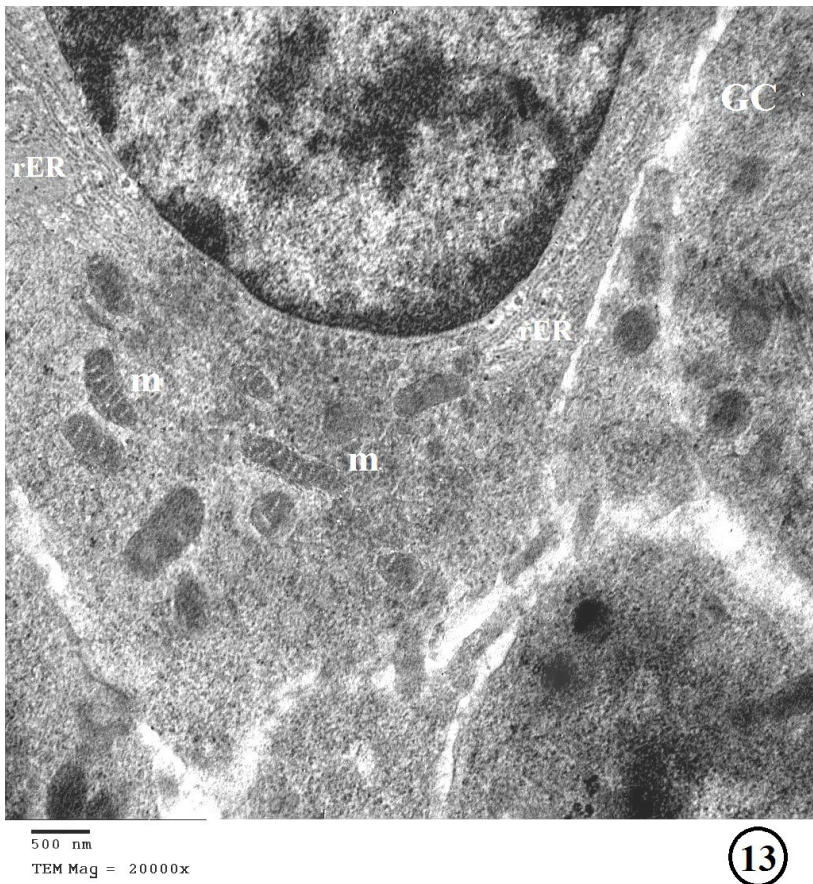

Fig. (13): An electron micrograph showing: oval to rounded apparently normal mitochondria $(\mathrm{m})$ with tubular cristae and parallel stacks of flattened cisternae of rough endoplasmic reticulum (rER) with lumina of relatively uniform size close to the nucleus of granulosa cells (GC).

Diabetic/MSC-x20000

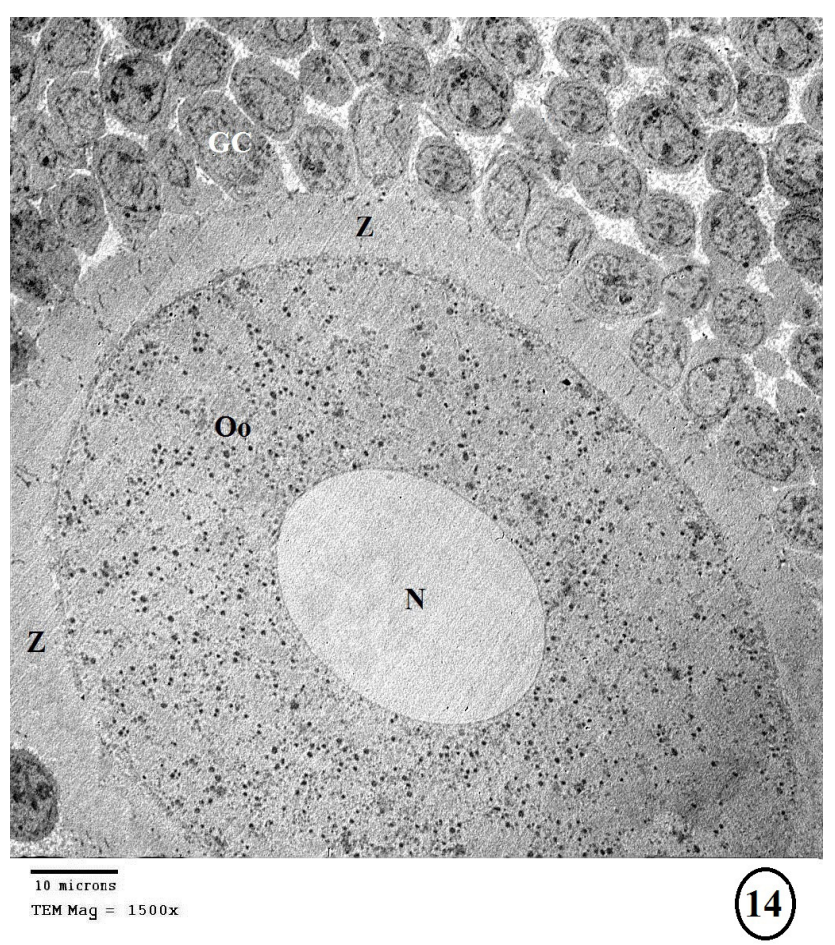

Fig. (14): An electron micrograph showing: large rounded oocyte (Oo) of multilaminar primary ovarian follicle has large spherical euchromatic nucleus $(\mathrm{N})$ surrounded by nuclear envelope. Notice, thick layer of welldeveloped electron semitranlucent zona pellucida $(Z)$ separates oocyte from the surrounding granulosa cells (GC). Diabetic $\backslash M S C-x 1500$ 


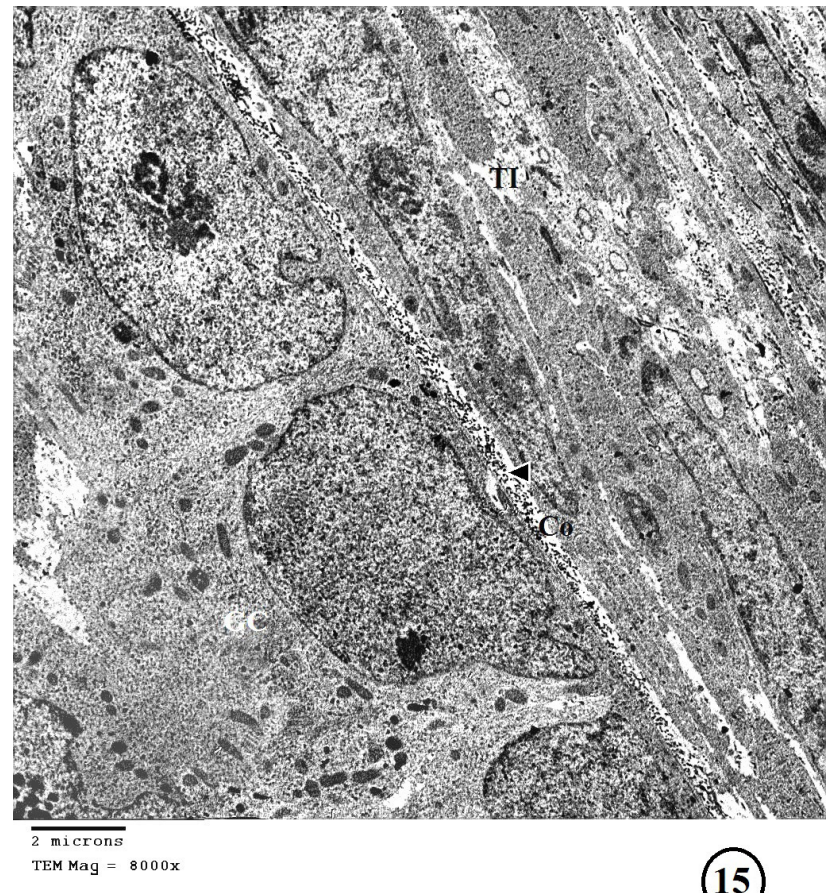

(15)

Fig. (15): An electron micrograph of part of mature Grafian follicle, showing: polyhedral granulosa cells (GC) having euochromatic nuclei (N) with shallow indentations. Notice, a basement membrane

surrounds the granulosa cell layer separating it from the theca interna cells ( TI) by a thin layer of collagen fibers (Co) cut in different directions

Diabetic/MSC/fennel-X8000

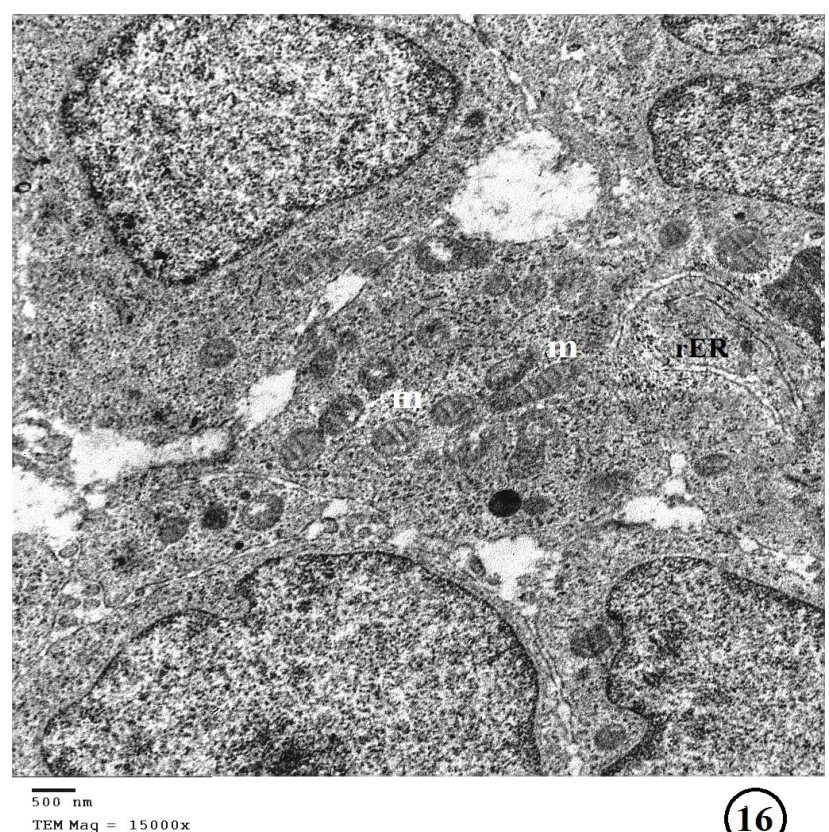

Fig. (16): An electron micrograph of part of mature Grafian follicle, showing spaces between granulosa cells contain liquor folliculi. Large polyhedral granulosa cells with euchromatic nuclei with shallow indentations. Notice, oval to rounded apparently normal mitochondria (m) with tubular cristae and parallel stacks of flattened cisternae of rough endoplasmic reticulum (rER) with lumina of relatively uniform size in cytoplasm of granulosa cells. Diabetic/MSC/fennel-X15000

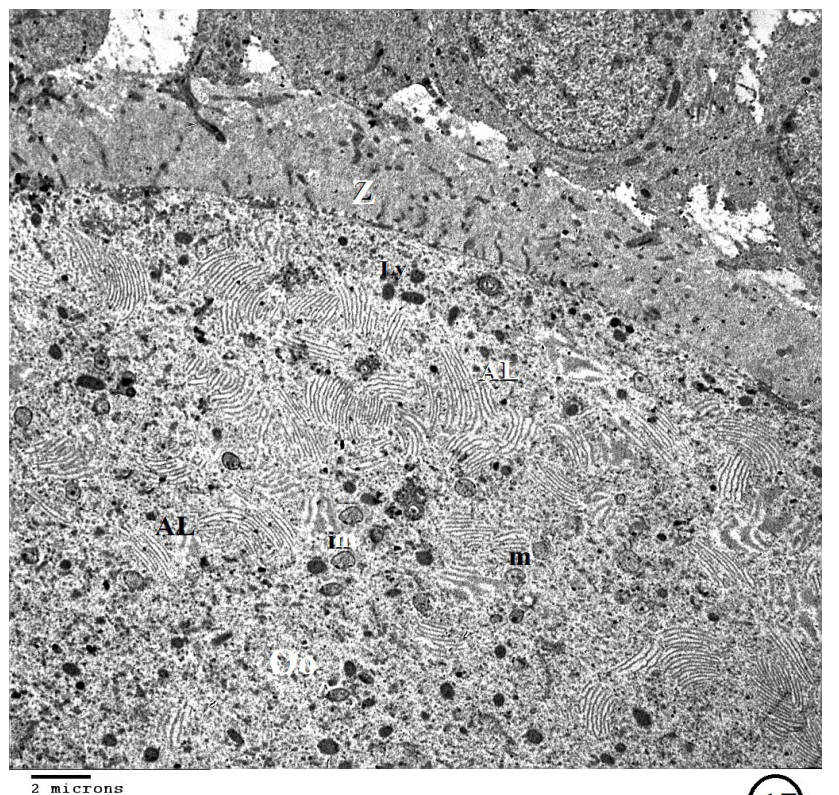

2 microns
TEM Mag $=5000 x$

Fig. (17): An electron micrograph showing : the oocyte (Oo) of mature Grafian follicle is surrounded by a thick layer of well-developed electron semitranlucent zona pellucida $(Z)$ separated it from the surrounding granulosa cells. Both oolema and plasma membrane of the granulosa cells are thrown into membranous finger-like microvilli that project into the zona pellucida. Notice, mitochondria (m) and abundant cytoplasmic stacks of annulate lamellae (AL) in the ooplasm.

Diabetic/MSC/fennel-X5000

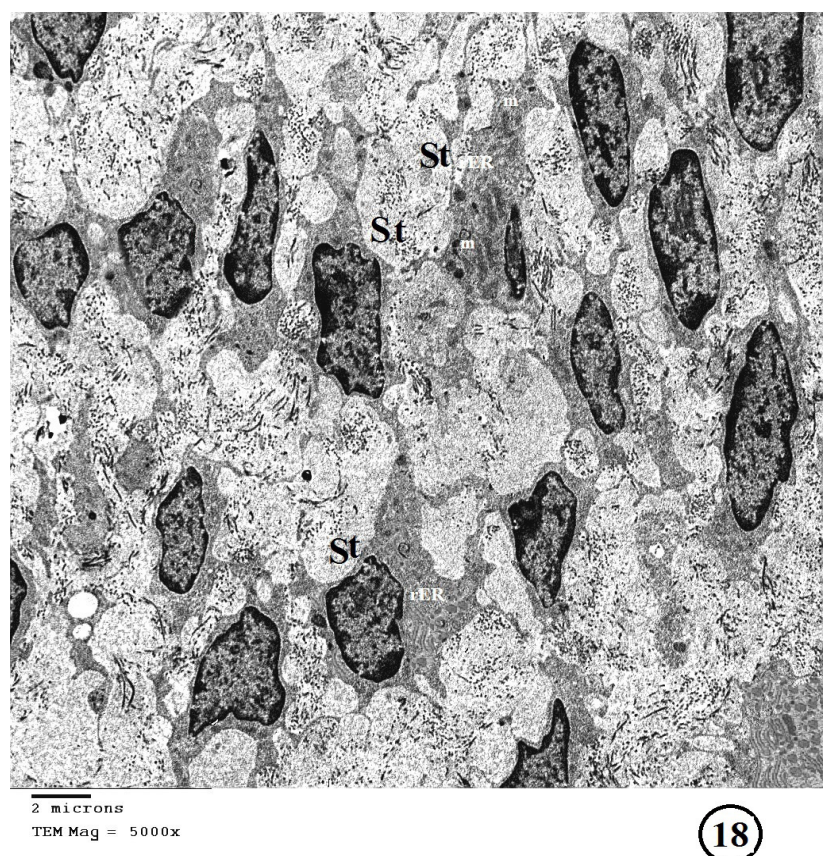

Fig. (18): An electron micrograph showing: widely dispersed long thin fibroblast-like stem cells (St) having long and thin cell processes. Notice, large irregularly shaped euchromatic nuclei with indentations. Heterochromatin around the nuclear margin is distinctly very pronounced. Several mitochondria $(\mathrm{m})$ and rough endoplasmic reticulum (rER) in the thick zone of cytoplasm, while a relatively thin peripheral rim of cytoplasm is poor in organelles. Diabetic/MSC/fennel-X 5000 
Sorour et al.

Table 1: The mean values of initial and final body weight (g) among all rats of the experimental groups.

\begin{tabular}{|c|c|c|c|c|c|c|}
\hline Items & $\begin{array}{c}\text { Group(I) } \\
\mathrm{N}=6\end{array}$ & $\begin{array}{c}\text { Group(II) } \\
\mathrm{N}=6\end{array}$ & $\begin{array}{c}\text { Group(III) } \\
\quad \mathrm{N}=6\end{array}$ & $\begin{array}{c}\text { Group(IV) } \\
\quad \mathrm{N}=6\end{array}$ & Test of significance & $P$ \\
\hline $\begin{array}{l}\text { Initial weight } \\
\text { mean }(g+S D)\end{array}$ & $291.6 \pm 18$ & $293 \pm 20$ & $289 \pm 11$ & $293 \pm 10$ & $\begin{array}{c}\text { ANOVA } \\
\mathrm{F}=0.09\end{array}$ & 0.9 \\
\hline $\begin{array}{l}\text { Final weight } \\
\text { mean }(g+S D)\end{array}$ & $338 \pm 13$ & $230 \pm 32$ & $340 \pm 20$ & $343 \pm 24$ & $\begin{array}{c}\text { ANOVA } \\
\mathrm{F}=34\end{array}$ & $0.000^{*}$ \\
\hline
\end{tabular}

$\mathrm{SD}=$ is the standard deviation

$\mathrm{N}=$ Number of animals

$*=P \leq 0.05=$ Significant

$P>0.05=$ Non significant

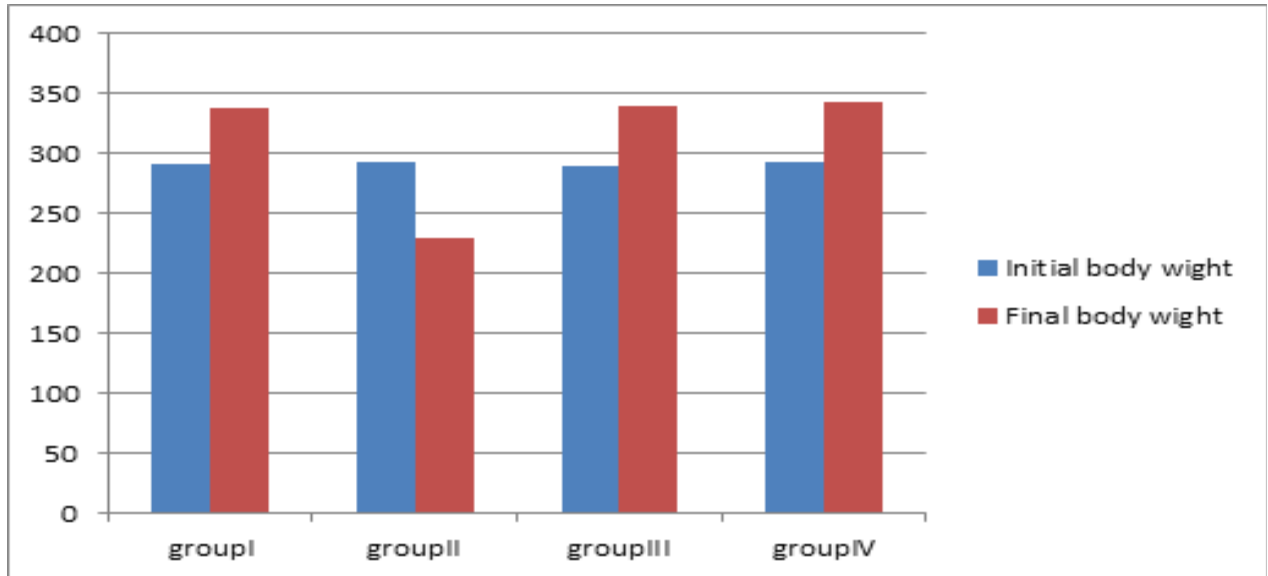

Histogram 1: The mean values of initial and final body weight $(\mathrm{g})$ among all rats of the experimental groups.

Table 2: The mean values of initial and final blood glucose levels (mg/dl) among rats of all experimental groups.

\begin{tabular}{|c|c|c|c|c|c|c|}
\hline Items & $\begin{array}{l}\text { Group(I) } \\
\mathrm{N}=6\end{array}$ & $\begin{array}{c}\text { Group(II) } \\
\mathrm{N}=6\end{array}$ & $\begin{array}{l}\text { Group(III) } \\
\quad \mathrm{N}=6\end{array}$ & $\begin{array}{l}\text { Group(IV) } \\
\quad \mathrm{N}=6\end{array}$ & Test of significance & $P$ \\
\hline $\begin{array}{l}\text { Initial glucose level } \\
\text { Mean (mg / dl) }\end{array}$ & $89 \pm 10$ & $301 \pm 31$ & $308 \pm 48$ & $336 \pm 49$ & $\begin{array}{c}\text { ANOVA } \\
\mathrm{F}=53\end{array}$ & $0.000^{*}$ \\
\hline $\begin{array}{l}\text { Final glucose level } \\
\text { Mean (mg / dl) }\end{array}$ & $107 \pm 9$ & $377 \pm 26$ & $96 \pm 13$ & $91.5 \pm 18$ & $\begin{array}{c}\text { ANOVA } \\
\mathrm{F}=379\end{array}$ & $0.000^{*}$ \\
\hline
\end{tabular}

$\mathrm{N}=$ Number of animals

$*=P \leq 0.05=$ Significant

$P>0.05=$ Non significant

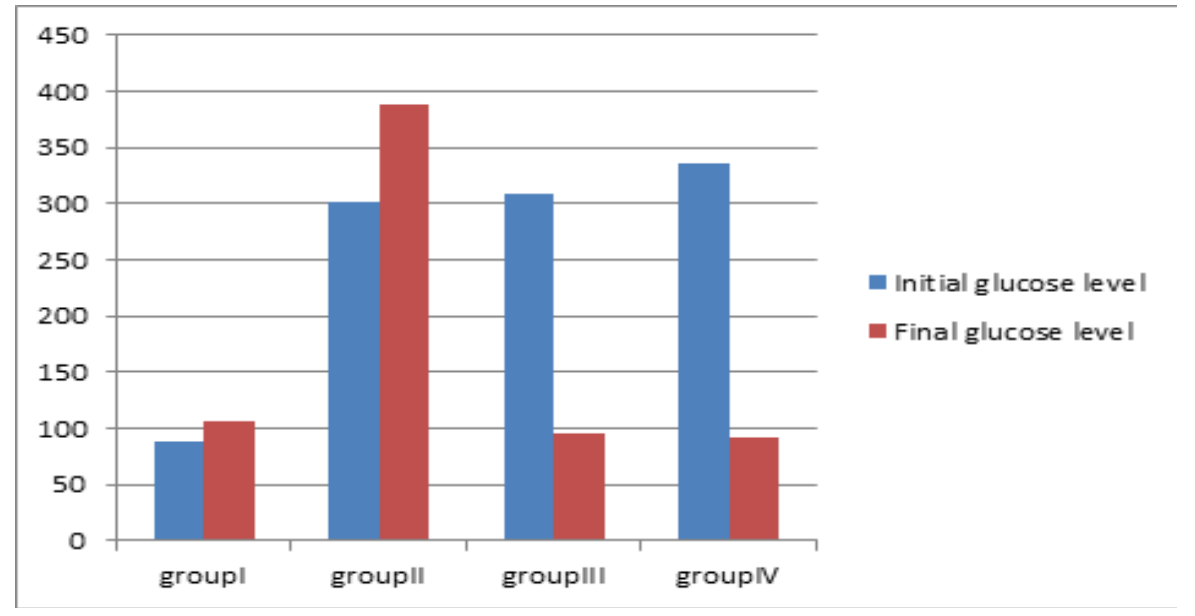

Histogram 2: The mean values of initial and final fasting blood glucose level (mg/dl) among all rats of the experimental groups. 
Table 3: The mean values of serum hormone levels of Estradiol (pg/ml), Progesterone (pg/ml) and Luteinizing Hormone (LH) (miu/ml) among rats of all experimental groups .

\begin{tabular}{|c|c|c|c|c|c|c|}
\hline Items & $\begin{array}{c}\text { Group(I) } \\
\mathrm{N}=6\end{array}$ & $\begin{array}{l}\text { Group(II) } \\
\mathrm{N}=6\end{array}$ & $\begin{array}{l}\text { Group(III) } \\
\quad \mathrm{N}=6\end{array}$ & $\begin{array}{l}\text { Group(IV) } \\
\mathrm{N}=6\end{array}$ & Test of significance & $P$ \\
\hline $\begin{array}{l}\text { LH mean } \\
(\mathrm{miu} / \mathrm{ml})\end{array}$ & $0.02 \pm 0.01$ & $0.071 \pm 0.044$ & $0.015 \pm 0.005$ & $0.013 \pm 0.005$ & $\begin{array}{c}\text { ANOVA } \\
\mathrm{F}=3.3\end{array}$ & $0.04 *$ \\
\hline $\begin{array}{c}\text { Estradiol } \\
\text { mean(pg/ml) }\end{array}$ & $16 \pm 2.8$ & $14.6 \pm 2.5$ & $31.5 \pm 7$ & $39.2 \pm 7$ & $\begin{array}{c}\text { ANOVA } \\
\mathrm{F}=31\end{array}$ & $0.000^{*}$ \\
\hline $\begin{array}{c}\text { Progestron } \\
\text { mean }(\mathrm{pg} / \mathrm{ml})\end{array}$ & $17 \pm 3$ & $6.6 \pm 1.4$ & $44.6 \pm 9$ & $51.5 \pm 7$ & $\begin{array}{c}\text { ANOVA } \\
\mathrm{F}=71\end{array}$ & $0.000^{*}$ \\
\hline
\end{tabular}

$\mathrm{N}=$ Number of animals

$*=P \leq 0.05=$ Significant

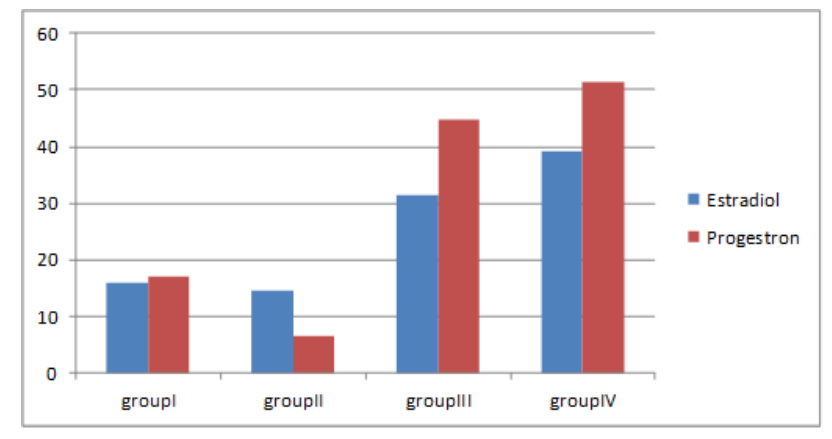

Histogram 3: The mean values of serum hormone levels of Estradiol (E2) $(\mathrm{pg} / \mathrm{ml})$ and Progesterone $(\mathrm{pg} / \mathrm{ml})$ among rats of all experimental groups at the end of 8 th week.

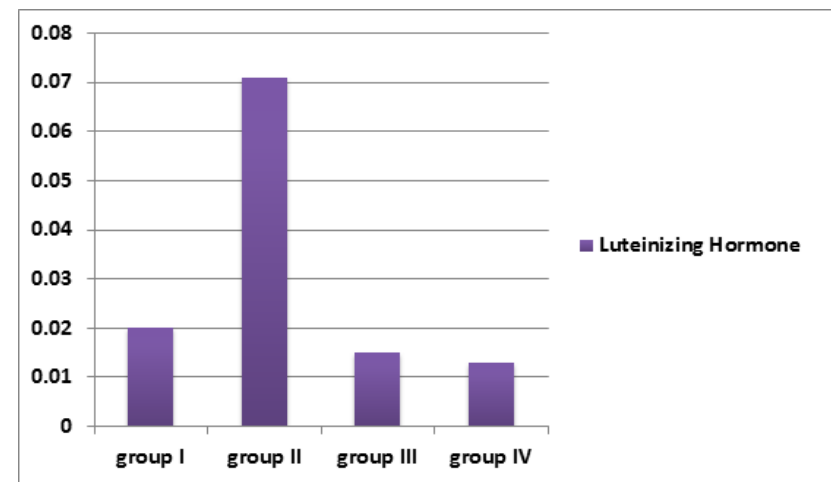

Histogram 4: The mean values of serum hormone level of Luteinizing Hormone $(\mathrm{LH})(\mathrm{miu} / \mathrm{ml})$ among rats of all experimental groups at the end of 8th week.

\section{DISCUSSION}

Aging and reproductive biology are two rapidly growing fields of modern biomedical researches. Aging process is of interest not only to scientists but also to public health ${ }^{[27]}$.

Several evidences suggest that menopause is concomitant with rapid progression of glucose intolerance, increased insulin resistance and high risk of developing type II diabetes and ovarian dysfunctions ${ }^{[28,29]}$.

To date, stem cells potentials have provided new hope for many patients who suffer from some diseases that currently have little or no therapeutic treatments. However, applications of stem cells have not been perfected of proven safe ${ }^{[30]}$.

Foeniculum Vulgare Mill (fennel) has attracted a great deal of interest among consumers and health care professionals for their potential benefits on human health ${ }^{[15]}$. Combination of herbs with systemic application of stem cells may help the body better manage the disease and plays a curative or protective role ${ }^{[31]}$.

The data from the present study on body weight showed that final body weight was significantly increased among diabetic mesenchymal stem cells treated rats (GIII) and diabetic mesenchymal stem cells treated and fennel oil ingested rats (GIV) respectively. On the contrary, the least body weight was significantly recorded among senile diabetic rats (GII).

This increase in body weight recorded in the control group is in consistence with the work of Elmquist et al. ${ }^{[32]}$, who explained that psychological stress as a consequence of menopause is a contributing factor in weight gain as it favors body to go into a storage mood. This "famine effect" increases levels of cortisol resulting in Cushingoid appearance in these postmenopausal women. In addition, decrease the conversion of tetraiodothyronine (T4) to free triiodothyronine (T3) leading to decrease metabolism, motor activity and increase obesity.

The reduction in body weight that was recorded among senile diabetic rats (GII) is in agreement with DeFronzo \& Tripathy ${ }^{[33]}$, who reported the association between insulin resistance in type 2 diabetes, elevated rates of lipolysis, increased plasma non esterified fatty acids (FFAs) and triglyceride concentrations with increased fat oxidation.

The data from the present study on measuring blood glucose levels showed a statistically significant increase in initial blood glucose level (3rd day after STZ intraperitoneal injection) among all STZ injected groups (GII, III, IV) above $200 \mathrm{mg} / \mathrm{dl}$.

On the other hand, there was marked improvement in the final blood glucose level at the end of the experiment (8th week) among all treated groups, diabetic mesenchymal stem cells treated rats (GIII) and diabetic mesenchymal stem cells treated / fennel oil ingested rats (GIV), when compared to rats of the diabetic group (GII). 
The studies of $\mathrm{Li} \& \mathrm{Fu}^{[34]}$; Li et al. ${ }^{[26]}$; De Miguel et al. ${ }^{[35]}$, have revealed that progenitor cells, promote tissue repair by secreting paracrine trophic factors as a part of their normal function, that inhibits pancreatic cell apoptosis, enhance the survival and functional recovery of the resident cells and permits the regeneration of pancreatic islets from endogenous progenitor cells of endocrine pancreas and also regulates the local microenviroment concomitantly with the reduction in blood glucose levels.

The therapeutic effect of MSCs is correlated to their anti-inflammatory action. This was a suggestion of Ezquer et $a l .{ }^{[36]}$; Freytes et al..$^{[37]}$; Zang et $a l . .^{[38]}$, who added that antidiabetic effect of systemically administered mesenchymal stem cells is not only related to their transdifferentiation potential but also to their immune response restoring the ratio between autoaggressive/ regulatory $\mathrm{T}$ cells and cytokines together with the modification of the pancreatic microenvironment.

The antidiabetic effect of fennel essential oil is in agreement with Faudale et al. ${ }^{[39]}$; De Sousa ${ }^{[40]}$; Shahat et al..$^{[41]}$; Bakkali et al. ${ }^{[42]}$; Osman et al. ${ }^{[43]}$. These authors mentioned that the hypoglycemic action in various seed extract of foeniculum vulgare is achieved by reducing intestinal disaccharides, high concentration of phytochemical constituents with the highest activity in scavenging superoxide radicals and other reactive oxygen species (ROS) generated during diabetes and lipid peroxidation inhibition via acting on both the cyclooxygenase and lipoxygenase pathways.

The data obtained from the present laboratory investigation on serum hormone levels; Estradiol (E2), Progesterone and Luteinizing Hormone (LH), showed that the least mean value of Estradiol and Progesterone levels, were recorded among diabetic rats (GII) that showed at the same time higher mean value of serum LH. On the other hand, treated groups (GIII, IV) showed significantly marked improvement of Estradiol and Progestron and LH levels when compared to rats of the diabetic group.

The disturbance in serum hormone levels that were recorded in diabetic group (GII) was explained by Gambineri et al. ${ }^{[44]}$. They stated that the main hormonal abnormalities in insulin resistant diabetic women include elevated androgen and estrogen levels over progesterone and commonly, but not always, an elevated LH: FSH ratio ending in polycystic ovary (PCO).

The marked improvement of Estradiol, Progestron and LH levels that were observed in bone marrow derived mesenchymal stem cells (BM-MSCs) treated rats (GIII,IV) is in agreement with the work of K"orbling \& Estrov $^{[45]}$, who attributed these changes to their high antiinflammatory efficiency, trophic effect that is part of their normal function, homing, integrating into the injured site and then finally transdifferentiate into tissue-specific.

Improvement of Estradiol, Progesterone and LH levels that were encountered in fennel oil treated rats (G IV) is in accordance with Sadeghpour et al..$^{[46]}$ Rahimikian et al. ${ }^{[47]}$. These authors in their study showed that fennel extract can significantly increase the serum level of estrogen in mice in comparison to control groups. They stated that fennel has a long history as an estrogenic agent, it contains different ingredients such as anol or dimethylatedanethole, which may have some estrogenic activity.

The current light microscopic results in diabetic animals (GII) showed classically, polycystic ovaries (PCO) that contained numerous peripheral small antral follicles. The granulosa lutein cells of corpus luteium had a large accumulation of intracytoplasmic vacuoles and degenerated nuclei. These results were confirmed by the electron microscopic finding of presence of numerous lipid droplets. Recent substantial theories have considered polycystic ovary (PCO) as a chronic, low-grade inflammatory disorder in obese and non obese diabetics ${ }^{[44]}$. Hyperglycemia may result in increased reactive oxygen species (ROS) production and oxidative stress that contribute to inflammation in polycystic ovary syndrome $(\mathrm{PCOS})^{[48]}$.

The previous authors added that a long lasting status of over produced toxic free radicals and insufficient antioxidant activity associated with impaired mitochondrial function may contribute to a pro-inflammatory state with the subsequent activation of nuclear transcription factorKappa-B (NF-kB) that initiate inflammatory cascade which may occur in reproductive disorders.

The noticed increase in the density and distribution of the collagenous fibers within the ovarian medulla of diabetic rats (GII) is in agreement with Dhindsa et al. ${ }^{[49]}$. These authors stated that fibrosis is simply the consequences of inflammation that associated with excess production of reactive oxygen species (ROS), apoptosis dysregulation, increase levels of proinflammatory cytokines and mediators in the blood, such as tumour necrosis factor alpha (TNF- $\alpha$ ), C-reactive protein levels, tissue plasminogen activator (t-PA) levels, transforming growth factor alpha or beta (TGF- $\alpha$ or $-\beta$ ) and increase the expression of multiple gene transcription factors such as activator protein-1 (AP$1)$ and nuclear transcription factor-Kappa-B (NF- $\kappa B)$ and decrease levels of anti-inflammatory cytokines.

Reduction in collagen distribution within ovarian medulla of the mesenchymal stem cell (MSC) treated rats (GIII,IV ) that seems more or less similar to the control explained by the work of Akram et al. ${ }^{[50]}$, who attributed that to the modulation of inflammatory and fibrotic processes. Evidences support a paracrine effect to enhance the survival and functional recovery of the resident and injured cells and more significantly regulating the local microenviroment, facilitates wound repair and reduce fibrosis.

Reduction in collagen distribution within ovarian medulla of the fennel oil treated rats (GIV) could be explained by the finding of Sadeghpour et al. ${ }^{[46]}$; Khazaei et al. ${ }^{[51]}$; Sabzghabaee et al. ${ }^{[52]}$, who concluded that the 
estrogenic effect of fennel oil provides anti-inflammatory protective role by acting on estrogen receptors, reduces inflammatory response and suppresses early apoptosis, cell death and fibrogenesis.

In all the present ovarian samples, cytoplasmic expression of estrogen receptor alpha $(\mathrm{ER} \alpha)$ that has been demonstrated by immunohistochemistry were positive in surface epithelial cells, luteanized cells of the corpus luteum and granulosa cells as well as theca layers from all stages of studied follicular categories, even in remnant cells of follicular cysts.

The present expression of ER $\alpha$ in the cystic follicles of diabetic animals with polycystic ovary (PCO) goes hand in hand with a previous study of Scully ${ }^{[53]}$, who observed in his study that ER $\alpha$ immunoreactivity in the ovary remained without significant changes in their distribution and localization in animals with and without the polycystic disease. Scully ${ }^{[53]}$ attributed ER $\alpha$ expression in PCO perhaps to chronically elevated circulating levels of luteinizing hormone that show a tendency to upregulate $\mathrm{ER} \alpha$ together with increasing estrogen levels in the follicular fluid, that usually are present in animals with this illness.However, there are no data available on the expression of ER $\alpha$ in cystic follicles and changes observed in cysts. More studies are necessary to fully understand and appreciate the implications of these observations.

The ovarian ultrastructural changes observed in diabetic rats (GII) were in the form of numerous variable sized electron lucent and electron dense lipid droplets together with abnormally expanded and swollen mitochondria that appeared with disrupted crista losing its internal organization. Ruptured or expanded rough endoplasmic reticulum, dilated Golgi bodies were also encountered. Enlarged irregular nuclei, increase spacing of the nuclear membranes or even reduced nucleoplasm and shrunken nuclei were observed in the diabetic group. These findings are in agreement with the work of Rabol et al. ${ }^{[54]}$, who attributed them to excess androgen and oxidative stress as most of these findings are the typical morphologic changes of all forms of hyperandrogenemea and highly activated steroidogenic cell.

Another explanation of the mitochondrial abnormalities came from Rabol et al..$^{[54]}$ and Yang et al..$^{[55]}$ who found in diabetes the oxidative stress play an important role in the pathogenesis leading to progressively degenerated mitochondria. They explained the mechanisms by the fact that oxidative stress alter bioenergetics and potentially increase reactive oxygen species (ROS) production.

The dilated rough endoplasmic reticulum that was observed in GII, is in agreement with Chen et al. ${ }^{[56]}$, who found that the abnormal number and shape of rough endoplasmic reticulum as a result of high accumulation of lipid droplets in the cytoplasm in association with damaged mitochondria may be related to excess androgen. They stated that an early major response to androgen excess is activation of certain synthesizing enzymes that are located at the rough endoplasmic reticulum leading to the stimulation of excess ribonucleic acid (RNA) synthesis.

The present study, revealed improvement in histological structure and ultrastructure in rat ovarian tissue of mesenchymal stem cell (MSC) treated rats (GIII) and when combined with fennel oil (GIV) leading to folliculogenesis with increased number of growing ovarian follicles. This is in agreement with the study of Dan et $a l .{ }^{[57]}$, who concluded that stem cell transplantation could help the recovery of ovarian function in some women who suffered premature menopause as a result of ovarian failure by chemotherapeutic agents

To our knowledge, there is no scientific report on the histological effect of Foeniculum vulgare Mill (fennel) on the ovary. However, improvement in histological structure and ultrastructure of ovarian tissue that were encountered in the ovary of fennel oil consuming rats ( GIV ) could be explained by the fact that fennel has an estrogenic effect. It contains different constituents, possessing estrogenic activity and providing protective role by acting on estrogen receptors increasing ovarian follicullogenesis in mice ovaries $^{[46,47,51]}$.

The presence of multiple Prussian blue positive $(+\mathrm{ve})$ polygonal, cuboidal and spindle shaped cells in-between the ovarian surface epithelium, the follicular cells of different ovarian follicles, granulosa lutein cells and even interstitial cells within the ovarian medulla were noticed in this study. It can be explained by the work of Takehara et $a l .{ }^{[58]}$, who noted that detection of hematopoietic mesenchymal stem cells (hMSCs) in the ovary, revealed a low number of hMSCs differentiation, which indicates that hMSCs migrated into the ovary may not differentiate directly into oocytes or granulosa cells and not directly participate in follicle regeneration but may survive in the interstitium in a resident state, playing important accessory roles in improving the microenvironment surrounding the oocytes in the ovary.

Souidi et al. ${ }^{[59]}$, believed that hematopoietic mesenchymal stem cells (hMSCs) function primarily by reactivating host oogenesis, which becomes impaired mainly in a reversible manner or by indirect effects on the microenvironment. Mesenchymal stem cells (MSCs) dramatically reduce apoptosis of granulosa cells in the developing follicles through secretion of stanniocalcin-1, paracrine factors and improve the oxide response pathway.

Careful observation is needed to determine whether stem cell transplantation constitutes regenerative cell therapy and to determine how long these injected cells can function in the ovary. Further experiments are necessary to elucidate the exact mechanisms by which stem cells improve organ function

\section{CONCLUSION}

The use of MSCs in regenerative medicine and tissue engineering makes them a promising therapy to treat diabetes mellitus and its complications. Also; fennel 
essential oil could be given to diabetic patients to ameliorate diabetes in addition to its use as a fertility enhancing agent.

\section{REFERENCES}

1. Beverley, B. and Eschwège, E. :The diagnosis and classification of diabetes and impaired glucose tolerance. In: Textbook of Diabetes. 3rd edition. Chapter 2. John C Pickup and Gareth Williams.2010; 1-11.

2. Torben, H.: Genetics of Type 2 diabetes. Curr Sci.2010; 83: 1477-1482.

3. Maori, L.; Ezekiel, D. and Bilal, J.: Prevalence of Diabetes in Zambuk General Hospital . Report and opinion . 2012; 4 (10): 54-57.

4. Kim, C.; Edelstein, S.L.; Crandall, J.P.et al.: Menopause and risk of diabetes in the Diabetes Prevention Program. Menopause. Journal of The North American Menopause Society.2011; 18 (8): 857-868.

5. Emanuela, F.; Grazia, M.; Marco, R.et al.: Inflammation as a Link between Obesity and Metabolic Syndrome. Journal of Nutrition and Metabolism; Review.2012; 8(1):1-7.

6. Brown, R.E. and Kuk, J.L.: Consequences of obesity and weight loss: a devil's advocate position.Obesity Reviews.2015;16:77-87.

7. Eshtiaghi, R.; Esteghamati, A. and Nakhjavani, M.: Menopause is an independent predictor of metabolic syndrome in Iranian women. Maturitas. 2010; 65 (3): 262-266.

8. Shifren, J.L. and Gass, M.L.S.: The North American Menopause Society Recommendations for Clinical Care of Midlife Women .Menopause. 2014; 21(10):1-25.

9. Hosseinifar, S.; Erfanimajd, N.; Morovvati, H. and Najafzadeh, H.: Diabetes (db/db) mutationinduced endometrial epithelial lipoapoptosis: Ultrastructural and cytochemical analysis of reproductive tract atrophy . American-Eurasian Journal of Toxicological Sciences. 2010; 3 (3): 197-203.

10. Taylor, A.E.; McCourt, B.; Martin, K.A. et al.: Determinants of abnormal gonadotropin secretion in clinically defined women with polycystic ovary syndrome. J Clin Endocrinol Metab.2010; 82(6): $2248-2256$.

11. Maiorino, M.I.; Bellastella.G. and Esposito, K.: sexual function in women with type 2 diabetes: current perspectives. J Sex Med. 2014; 7: 95-105.

12. Harshit, R.; Shah, A.A.; Pravir, K. and Rashmi, K.A.: Protective effects of transplanted bone marrow mononuclear cells (BMMNCs) in organ damage caused due to streptozotocin (STZ) induced diabetes. African Journal of Pharmacy and Pharmacology.2011; 5 (23): 2605-2612.

13. Pratik, M.P.: Bone Marrow Derived Mesenchymal Stem Cells -A Boon for the Treatment of Complications in Diabetes Mellitus. International Journal of Pharmaceutical and Phytopharmacological Research.2011; 1 (3): 134139.

14. Vassena, R.; Eguizabal, C.; Heindryckx, B. et al.: Stem cells in reproductive medicine: ready for the patient? .Human Reproduction. 2015; 1: $1-8$.

15. Yang, W.; Lu, J.; Weng, J. et al.: China National Diabetes and Metabolic Disorders Study Group. Prevalence of diabetes among men and women in China. N Engl J Med.2010; 362: 1090-1101.

16. Abou El-Soud, N.H.; El-Laithy, N.; El-Saeed, G.et al.: Antidiabetic Activities of Foeniculum Vulgare Mill. Essential Oil in Streptozotocin-Induced Diabetic Rats .Macedonian Journal of Medical Sciences.2011; 6 (2): 1-8.

17. Rivera, J.O.; Loya, A.M. and Ceballos, R.: Use of Herbal Medicines and Implications for Conventional Drug Therapy Medical Sciences. Alternative and Integrative Medicine. 2014; 3:2-6.

18. He, W. and Huang, B.: A review of chemistry and bioactivities of a medicinal spice: Foeniculum vulgare . Journal of Medicinal Plants Research. 2011; 5(16): 3595-3600.

19. Abu Abeeleh, M.; Bani Ismail, Z.; Alzaben, K.R.et al. : Induction of Diabetes Mellitus in Rats Using Intraperitoneal Streptozotocin: A Comparison between 2 Strains of Rats . European Journal of Scientific Research. 2010; 32 (3): 398-402.

20. Shah, H.R.; Arivarasan, A.; Kumar, P. and Ambasta, R.K.: Protective effects of transplanted bone marrow mononuclearcells (BMMNCs) in organ damage caused due tostreptozotocin (STZ) induced diabetes . Research. African Journal of Pharmacy and Pharmacology. 2011; 5 (23): 26052612.

21. Ellis, R.: Perls Prussian Blue Stain Protocol, Pathology Division, Queen Elizabeth Hospital. South Australia. 2007.

22. Elmlinger, M.W.; Kühnel, W. and Ranke, M.B.: Reference ranges for serum concentrations of lutropin (LH), follitropin (FSH), estradiol (E2), prolactin, progesterone, sex hormone-binding globulin (SHBG), dehydroepiandrosterone sulfate (DHEAS), cortisol and ferritin in neonates, children and young adults. Clin Chem Lab Med.2008; 40 (11): 1151-1160.

23. Bancroft, J.D. and Gamble, M.: In: Theory and practice of histological Techniques, 6th edition. 
Churchill Livingstone, Edinburgh, London, Melbourne.2007; 201-217.

24. Drury, R.A. and Wallington, E.A.: Carleton's histological technique, 5th edition. Oxiford University Press. London, New York and Toronto. $1980 ; 139-142$ and 182-184.

25. Williams, D.B. and Carter, C.B.: Transmission Electron Microscopy. A Textbook for Materials Science. 2nd edition, Springer - Verlag. Berlin. Heidelberg, New York, London.1996; 721-756.

26. Li, W.L.; Ren, G.; Huang, Y. et al.: Mesenchymal stem cells: a double-edged sword in regulating immune responses. Cell Death and Differentiation. 2012; 19 (3): 1505-1513.

27. Anzalone, C.R.; Hong, L.; Lu, J.K.H. and Polt, P.S.: Influences of age and ovarian follicular reserve on estrous cycle patterns, ovulation, and hormone secretion in the Long-Evans rat. Biol Reprod.2009; 64: 1056-1062.

28. Choi, S.B.; Jang, J.S. and Park, S.L.: Estrogen and exercise may enhance beta-cell function and mass via insulin receptor substrate 2 induction in ovariectomized diabetic rats. Endocrinology. 2009;146 (21) : 4786-4794.

29. Rogers, N.H.; Witczak, C.A.; Hirshman, M.F. et al.: Estradiol stimulates Akt, AMP-activated protein kinase (AMPK) and TBC1D1/4, but not glucose uptake in rat soleus. Biochem Biophys Res Commun.2009; 382 (11) : 646- 650.

30. Didié, M.; Christalla, P.; Rubart, M . et al.: Parthenogenetic stem cells for tissue-engineered heart repair.J Clin Invest.2013;123 (3): 1285-1298.

31. Shen, J.P.1.; Ye, B.D. and Zhou, Y.H.: Treatment of refractory severe autoimmune disease by combined therapy with Chinese herbs and autohemopoietic stem cell transplantation. Zhongguo Zhong Xi Yi Jie He Za Zhi.2010; 28 (3): 212-225.

32. Elmquist, J.K.; Ahima, R.S.; Elias, C.F. et al.: Leptin activates distinct projections from the dorsomedial and ventromedial hypothalamic nuclei. Proc Natl Acad Sci USA.2007; 95 (2): 741 746.

33. DeFronzo, R.A. and Tripathy, D.: Skeletal Muscle Insulin Resistance Is the Primary Defect in Type 2 Diabetes . Diabetes Care. 2009; 32 (2): S157S163.

34. Li, H. and Fu, X.: Mechanisms of action of mesenchymal stem cells in cutaneous wound repair and regeneration.Cell Tissue Res. 2012; 348 (3): $371-377$.

35. De Miguel, M.P.; Fuentes-Julian, S.; BlazquezMartinez, A. et al.: Immunosuppressive properties of mesenchymal stem cells: advances and applications. Current Molecular Medicine.2012; 12 (5): 574-591.

36. Ezquer, F.; Ezquer, M.; Contador, D. et al.: "The antidiabetic effect of mesenchymal stem cells is unrelated to their transdifferentiation potential but to their capability to restore Th1/Th2 balance and to modify the pancreatic microenvironment," Stem Cells.2012; 30 (8): 1664-1674.

37. Freytes, D.O.; Kang, J.W.; Marcos-Campos, I. et al.: "Macrophages modulate the viability and growth of human mesenchymal stem cells," Journal of Cellular Biochemistry. 2013; 114 (1): 220-229.

38. Zang, Li; Hao, H; Liu, J; Li, Y; , Han, W and $\mathrm{Mu}, \mathrm{Y}$ : : Mesenchymal stem cell therapy in type 2 diabetes mellitus .Diabetology \& Metabolic Syndrome .2017; 9(36):1-11.

39. Faudale, M.; Viladomat, F.; Bastida, J. et al.: Antioxidant activity and phenolic composition of wild, edible, and medicinal fennel from different mediterranean countries. J. Agric. Food Chem.2008; 56 (4): 1912-1920.

40. De Sousa, D.P.: Analgesic-like Activity of Essential Oils Constituents. Molecules. 2011; 16 (3): 2233-2252.

41. Shahat, A.A.; Ibrahim, A.Y.; Hendawy, S.F. et al:: Chemical composition, antimicrobial and antioxidant activities of essential oils from organically cultivated fennel cultivars. Molecules. 2011; 16 (2): 1366-1377.

42. Bakkali, F.; Averbeck, S.; Averbeck, D. and Idaomar, M.: Biological effects of essential oils. Food and Chemical Toxicology.2012; 46 (7): 446475.

43. Osman, N. N.; Jambi, E. J.1; Aseri, N. H.: Assessment of antidiabetic and antioxidant activities of Cassia angustifolia and Feoniculum vulgare in diabetic rats. Int.J. Pharm. Res. Allied Sci. 2017; 6(2):149-162.

44. Gambineri, A.; Patton, L.; Altieri, P. et al.: Polycystic ovary syndrome is a risk factor for type 2 diabetes: results from a long-term prospective study. Diabetes. 2012; 61 (9): 2369-2374.

45. K"orbling, M. and Estrov, Z.: "Adult stem cells for tissue repair - a newtherapeutic concept?" New England Journal of Medicine. 2012; 349 (6): 570-582.

46. Sadeghpour, N.; Khaki2, A.A.; Najafpour, A. et al.: Study of Foeniculum vulgare (Fennel) Seed Extract Effects on Serum Level of Estrogen, Progesterone and Prolactin in Mouse. Crescent J Med \& Biol Sci. 2015; 2 (1): 23-27. 
47. Rahimikian, F.; Rahimi, R.; Golzareh, P.;Bekhradi, R.; and Mehran, A. : Effect of Foeniculum vulgare Mill. (fennel) on menopausal symptoms in postmenopausal women: a randomized, tripleblind, placebo-controlled trial. Menopause.2017; 24(9): 1017-1021.

48. Rezvanfar, M.A.; Ahmadi, A.; Shojaei, H.A. et al.: "Mechanistic links between oxidative/nitrosative stress and tumor necrosis factor alpha in letrozoleinduced murine polycystic ovary Biochemical and pathological evidences for beneficial effect of pioglitazone," Human \& Experimental Toxicology. 2011; 31 (9): 887-897.

49. Dhindsa, G.; Bhatia, R.; Dhindsa, M. and Bhatia, V.: Insulin resistance, insulin sensitization and inflammation in polycystic ovarian syndrome. $\mathrm{J}$ Postgrad Med. 2008; 50 (2): 140-144.

50. Akram, K.M.; Samad, S.; Spiteri, M.A. and Forsyth, N.R.: Mesenchymal stem cells promote alveolar epithelial cell wound repair in vitro through distinct migratory and paracrine mechanisms. Respir Res. 2013; 14: 1-9.

51. Khazaei, M.; Montaseri, A.; Khazaei, M.R. and Khanahmadi, M.: Study of Foeniculum vulgare Effect on Folliculogenesis in Female Mice .Int J Fertil Steril. 2011; 5 (3): 122-127.

52. Sabzghabaee, A.M.; Nili, F.; Ghannadi, A. et al.: Role of menthol in treatment of candidial napkin dermatitis. World Journal of Pediatrics.2011; 7 (1):
167-170.

53. Scully, R.E.: Pathology of ovarian cancer precursors. J Cell Biochem. 2009; 23 (2): 208-218.

54. Rabol, R.; Boushel, R. and Dela, F.: Mitochondrial oxidative function and type 2 diabetes. Applied Physiology. Nutrition, and Metabolism. 2012; 31 (4): 675-683.

55. Yang, Y.; Tsou, C.S.; Lee, T.C. et al.: Distribution of 127 edible plant species for antioxidant activities by two assays. J Sci Food Agric. 2013; 86 (13): 2395-2403.

56. Chen, Q.; Sun, X.; Chen, J. et al:: Direct rosiglitazone action on steroidogenesis and proinflammatory factor production in human granulosa-lutein cells. Reprod Biol Endocrinol. 2009; 7: 147-154.

57. Dan, S.; Haibo, L. and Hong, L.: Pathogenesis and stem cell therapy for premature ovarian failure. OA Stem Cells. 2014; 10 (1): 1-8.

58. Takehara, Y.; Yabuuchi, A. and Ezoe, K. et al.: "Therestorative effects of adipose-derived mesenchymal stem cells on damaged ovarian function," Laboratory Investigation. 2013; 93 (2): 181-193.

59. Souidi, N.; Stolk, M. and Seifert, M.: "Ischemiareperfusion injury: beneficial effects of mesenchymal stromal cells," Current Opinion in Organ Transplantation. 2013; 18: 34-43. 


$$
\text { الملخص العربى }
$$

\title{
ما مدى امكانية حقن الخلايا الجذعية وتناول الثمر في تغيير التركيب

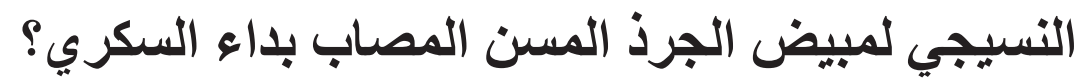

\author{
'حكمت احمد سرور، 'فاطمة سيد عبد العال، ‘هالة جبر،'منى محمد عبد الجليل \\ اقوم الهستولوجيا ـ كلية طب (بنات)- جامعة الازهر \\ بقسم التحاليل الباثولوجية ـ كلية الطب ـ جامعة القاهرة
}

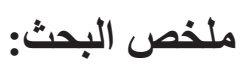
لا تز ال العلاقة بين انقطاع الطمث و البول السكري موضع جدل ــومع ذلك، فقد اشـارت التجارب السريرية إلى وجود ارتباط محتمل بين انقطاع الطمث وما يعقبه من مضاعفات مرض السكري. حيث ثبت ان خلل الجهاز التناسلي هو النتيجة المتوقعة من متلازمة مرض السكري. وان هنالك ارتباط وثيق بين السمنة وداء السكري وما يعقبه من نشو هات في الوظيفة التناسلية للإناث. وتنتخدم عادة في هذه الأيام النباتات و التوابل الطبية التقليدية المتعارف عليها لآثار ها المحتملة في الحد من ارتفاع السكر في الدم ,كمضاد لداء السكري وكعامل معزز للخصوبة بدلا من استخدام العقاقير الصناعية. ونشير الدراسات الحديثة الي أن الخلايا الجذعية هي وسيلة واعدة لعلاج مجموعة متنوعة من الأمر اض، بما في ذلك خلل الجهاز التناسلي. الهزف من البحث: تهدف هذه الدر اسة الى تقييم دوركلا من الخلايا الجذعية وتناول الثمرفي تحسين تشوهات المبيض المرضية الناجمة عن مرض السكري المستحدث في الجرذان المسنة. المواد و الطرق: - مئ

تم اجر اء هذا البحث على اربعة وعشرين جرذا نم تقسيمه بالتساوى الى اربع مجموعات. المجموعة الضابطة، مجمو عة داء السكري، مجمو عة داء السكرى المعالجة بالخلايا الجذعية ومجمو عة داء السكرى المعالجة بكل من زيت الثمر و الخلايا الجذعية .وقد استمرت التجربة لمدة ^ أسابيع،و عند نهاية مدة التجربة تم جمع عينات المبيض للار اسات النسيجية والتركيب الدقيق, و الدراسة الهستوكيميائية المناعية.كما قدرت مستويات السكر في الدم وأجريت التحاليل الهرمونية في الدم. الأتنائجج:

أظهرت نتائج الفحص المجري تكيس المبايض حيث احتوت المبايض على العديد من الجريبات في مجموعة داء السكرى فقط وارتفاع مستوى السكر في الدم. بينما أظهرت المجموعات المعالجة بالخلايا الجذعية بعض التحسن 
الملحوظ في التركيب النسيجي للمبيض وخفض مستوى السكر في الدم .وأظهرت المجمو عة المعالجة بكل من الخلايا الجذعية والثمر دور فعال وو اضح في استعادة هيكلة المبيض و علاج تكيس المبيض مصاحبا ذلك تأثثير ها الملحوظ على تحسين مستوي السكر بالدم في الجرذان المصابة بداء السكري.

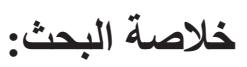

في ضوء نتائج العمل الحالي ، تم تأكيد العلاقة بين كفاءة الخلايا الجذعية في الطب التجديدي و تجدد الانسجة مما يجعلها علاجاو اعدا لمرض السكري ومضاعفاته. كما توضح هذه الدر اسة حقيقة دور الثمر في تحسين مستويات السكر لمرضى السكري اضافة الى استخدامه كعامل معزز للخصوبة. 